\title{
Article \\ Radon over Kimberlite Pipes: Estimation of the Emanation Properties of Rocks (Lomonosov Diamond Deposit, NW Russia)
}

\author{
Evgeny Yakovlev*(i) and Andrey Puchkov \\ N. Laverov Federal Centre for Integrated Arctic Research of Ural Branch of the Russian Academy of Sciences, \\ 109 Severnoj Dviny Emb., 163000 Arkhangelsk, Russia; vp-andrew@list.ru \\ * Correspondence: evgeny.yakovlev@fciarctic.ru; Tel.: +7-931-401-41-08; Fax: +7-8182-28-76-36
}

Citation: Yakovlev, E.; Puchkov, A. Radon over Kimberlite Pipes:

Estimation of the Emanation

Properties of Rocks (Lomonosov

Diamond Deposit, NW Russia). Appl. Sci. 2021, 11, 6065. https://doi.org/ 10.3390/app11136065

Academic Editor:

Giuseppe Lacidogna

Received: 20 April 2021

Accepted: 24 June 2021

Published: 29 June 2021

Publisher's Note: MDPI stays neutral with regard to jurisdictional claims in published maps and institutional affiliations.

Copyright: (c) 2021 by the authors. Licensee MDPI, Basel, Switzerland. This article is an open access article distributed under the terms and conditions of the Creative Commons Attribution (CC BY) license (https:// creativecommons.org/licenses/by/ $4.0 /)$.

\begin{abstract}
In this paper, using the example of the Lomonosov diamond deposit, experimental studies of rocks were carried out to assess the main radiation and physical factors affecting the formation of the radon field over the kimberlite pipes of the Arkhangelsk diamondiferous province. For various types of rocks, represented by vent kimberlites, tuffaceous-sedimentary rocks of the crater and enclosing and overlying sediments, the following were studied: porosity, density, activity of radium226 , activity of radon in a free state, level of radon production, and emanation coefficient. The research results showed that the greatest amount of radon in a free state is produced by rocks of the near-pipe space, represented by the enclosing Vendian $V_{2}$ deposits and characterized by high values of the emanation coefficient, radium activity, radon production level and porosity. This fact is associated with the structural and geological features of the near-pipe space, which was exposed to the impact of kimberlite magma on the host rocks. The lowest values of these parameters are characteristic of the kimberlites of the vent facies, which limits the formation of free radon in the body of the pipe. The results of the experimental studies create prospects for the development of emanation methods for searching for kimberlite pipes in the conditions of the Arkhangelsk diamondiferous province.
\end{abstract}

Keywords: radon field; kimberlites; Arkhangelsk diamondiferous province; emanation coefficient; radon production rate; porosity; density

\section{Introduction}

Radon is part of the decay chain of the uranium-238 radioactive family and is continuously formed in natural environments during the radioactive decay of its parent isotope, radium-226, the half-life of which is about 1600 years [1-5]. Being an inert gas with a relatively long half-life (3.82 days), in terms of its physical and chemical properties, it acts as an optimal indicator for studying many processes occurring in the environment [4,6-8], including several important geological processes $[9,10]$. This is due to the fact that radon gas shows the ability to easily migrate in the geological environment in the gas phase or dissolved in pore waters [3,11-13], forming a radon field with the appearance of emanation anomalies in the near-surface horizons of rocks and soils [3,14,15]. In this regard, emanation methods began to be widely used in geochemical, geophysical and geodynamic studies to track geological processes [4]. Emanation methods are also used in the search for mineral deposits, including kimberlites [16-19]. Emanation studies carried out in the territory of the kimberlite fields of the Arkhangelsk diamondiferous province (Russian Federation) showed that, in the soil horizons above the kimberlite bodies, there are increased values of the volumetric activity of radon that are several times higher than the background values [20]. It was shown that the nature of the distribution of radon over kimberlite pipes has a subcircular structure, which is associated with the development of faults and fracturing in the enclosing rocks of the near-pipe space $[19,21]$. Previously obtained data have shown high prospects for the application of emanation methods in the search for kimberlite pipes in the territory of the Arkhangelsk diamondiferous province [22]. 
However, for a more complete understanding of the specifics of locating explosion pipes in the field of radon volumetric activity and the development of emanation methods to search for kimberlites, it is necessary to conduct detailed studies of the mechanisms and conditions of radon formation in the rocks that compose the kimberlite body. The purpose of this study was to study the emanation properties of rocks that make up the kimberlite pipes of the Arkhangelsk diamondiferous province, so the radiation and physical parameters of the kimberlites that overlap and the host rocks of the Lomonosov diamond deposit of the Arkhangelsk diamondiferous province were studied. The following radiation and physical parameters were studied: activity of radium-226, activity of radon-222, emanation coefficient, radon rate production, average and true density, and porosity. An assessment of the main factors causing the formation of the increased activity of radon over the pipes has been carried out.

\section{Material and Methods}

The Lomonosov diamond deposit of the Arkhangelsk diamondiferous province is located $\sim 90 \mathrm{~km}$ northeast of Arkhangelsk, forming a chain about $20 \mathrm{~km}$ long with a strike north-north-east. The deposit consists of six kimberlite pipes: Arkhangelskaya, Karpinsky1, Karpinsky-2, Pionerskaya, Lomonosovskaya, and Pomorskaya (Verzhak et al. 2008). Currently, only two pipes (Arkhangelskaya and Karpinsky-1) are being developed by quarries. The location and geological structure of the Lomonosov diamond deposit is shown in Figure 1.

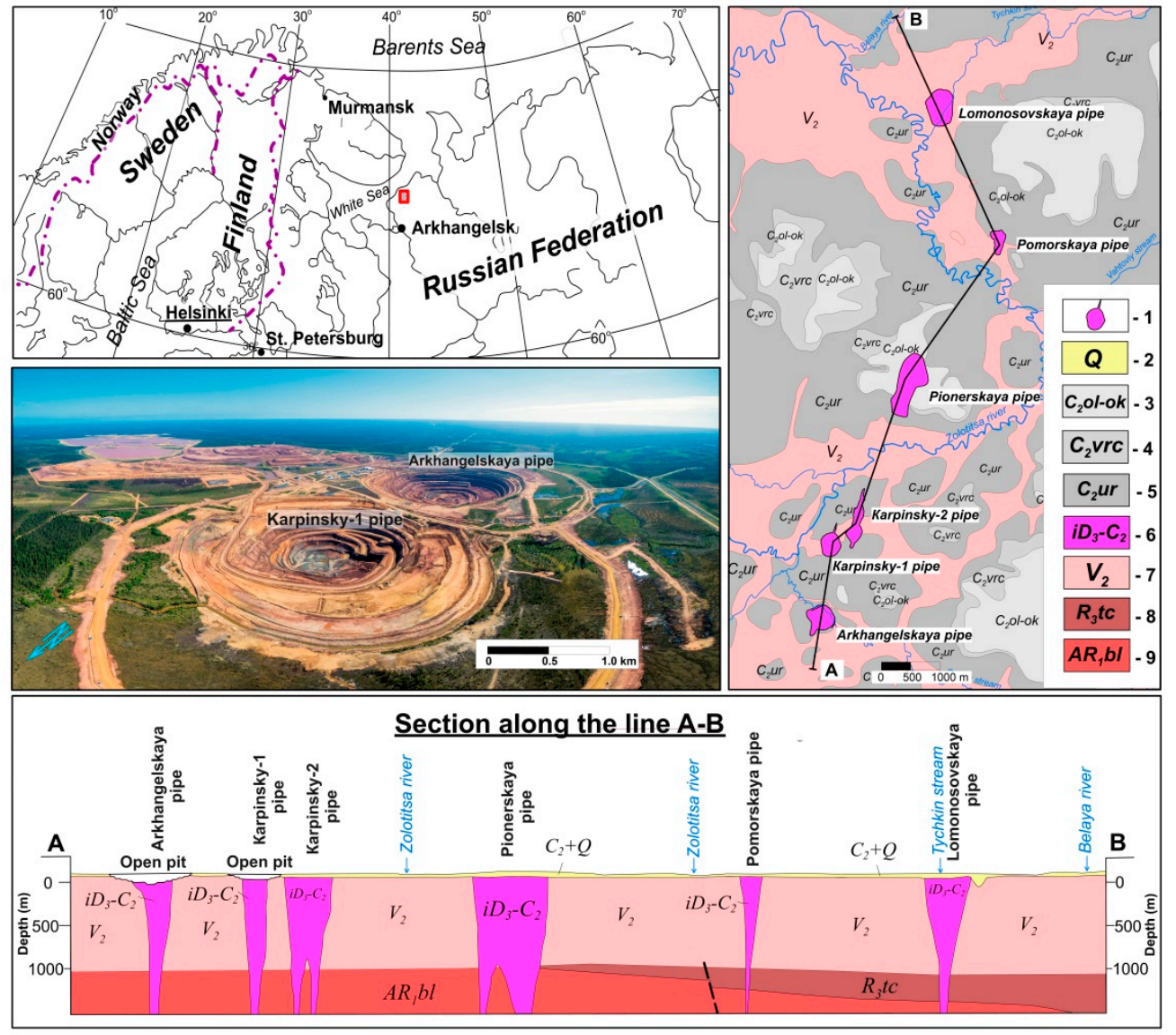

Figure 1. The location of the study area and the geological structure of the Lomonosov diamond deposit. 1-Kimberlite pipe; 2-Quaternary fluvioglacial sediments; 3-5-Middle Carboniferous sediments: 3-Olmugo-Okunev suite; 4-Voevchensky suite; 5 -Ursug suite; 6-Kimberlites: Upper Devonian-Middle Carboniferous; 7-Upper Vendian sediments; 8-Upper Riphean: Tokminskaya suite; 9-Archean: Belozersky complex. 
The sampling of rocks was carried out in the quarries of the Arkhangelskaya (N65.2913, E41.0209) and Karpinsky-1 (N65.3018, E41.0246) kimberlite pipes, together with the geologist of the mining plant (Figure 1). In total, 30 rock samples were taken, weighing up to $2 \mathrm{~kg}$ each. Rocks are represented by various types of deposits from quarries up to $186 \mathrm{~m}$ deep (from top to bottom): overlying Quaternary $(\mathrm{Q})$ and Carboniferous rocks $\left(\mathrm{C}_{2}\right)$, Vendian host rocks $\left(\mathrm{V}_{2}\right)$, tuffaceous sedimentary crater rocks $\left(\mathrm{iD}_{3}-\mathrm{C}_{2}\right)$ and vent facies kimberlites $\left(\mathrm{iD}_{3}-\mathrm{C}_{2}\right)$. A detailed description of the geological structure of the Lomonosov diamond deposit was presented by Yakovlev (2020) [22]. Typical geology cross-section of kimberlite pipe of the Lomonosov diamond deposit is in Appendix B. After delivery to the laboratory, rock samples were dried in a BINDER E28 drying oven at $105^{\circ} \mathrm{C}$ to an air-dry state. The determination of the radiation and physical parameters of the rocks was carried out in the laboratory of environmental radiology, which complies with the accreditation criteria for testing laboratories established in ISO/IEC 17025. The analytical procedures are described below. Typical Types of the Studied Rocks from the Lomonosov Diamond Deposit are shown in Appendix C.

\subsection{Gamma Spectrometry Measurements}

The method of gamma spectrometry is widely used to measure gamma radiation from radionuclides of natural origin, including ${ }^{226} \mathrm{Ra}$, because it is a universal, non-destructive and easy-to-use method, especially at the stages of sample preparation and in the measurement process $[23,24]$. To determine radionuclide ${ }^{226} \mathrm{Ra}$ in rocks, we used a semiconductor gamma-spectrometric complex with nitrogen cooling ORTEC with a GEM 10 P4-70 HPGe detector (Ametek Ortec, Oak Ridge, TN, USA) complete with lead shielding. The resolution of the gamma spectrometer along the $1.33 \mathrm{MeV}\left({ }^{60} \mathrm{Co}\right)$ line is $1.75 \mathrm{keV}$, and the relative efficiency is $15 \%$. The measurement geometry was a 1-L Marinelli vessel (counting sample).

The activity of the ${ }^{226} \mathrm{Ra}$ radionuclide, taking into account the accumulation, was determined from the radionuclide ${ }^{214} \mathrm{~Pb}(351.93 \mathrm{keV}$ with a quantum yield of $35.60 \%)$ and ${ }^{214} \mathrm{Bi}(609.32 \mathrm{keV}$ with a quantum yield of $45.49 \%, 1120.29 \mathrm{keV}$ with a quantum yield of $14.92 \%, 1764.49 \mathrm{keV}$ yield-15.3\%).

The values of the activity of ${ }^{226} \mathrm{Ra}$, determined from its daughter decay products, and the activity of ${ }^{226} \mathrm{Ra}$, experimentally determined from its own gamma radiation $(186.21 \mathrm{keV})$, coincided within at least $90 \%$. Both methods of the registration of the ${ }^{226} \mathrm{Ra}$ radionuclide (by its own gamma radiation and by the gamma radiation of its decay products) have their own advantages and disadvantages [25].

In the experimental determination of the specific activity of the ${ }^{226} \mathrm{Ra}$ radionuclide from its gamma radiation, the presence of the uranium-235 radionuclide, with its gamma radiation energy of $185.72 \mathrm{keV}$, was taken into account, the activity of which can be determined from the lines $63.29 \mathrm{keV}$ and $92.80 \mathrm{keV}\left({ }^{234} \mathrm{Th}\right)$. This experimental method for the determination of ${ }^{226} \mathrm{Ra}$ is applicable only for natural environments that are almost always characterized by a constant ratio of ${ }^{235} \mathrm{U} /{ }^{238} \mathrm{U}$ radionuclides and the presence of a radioactive equilibrium between ${ }^{238} \mathrm{U}$ and ${ }^{234} \mathrm{Th}$ radionuclides [26].

\subsection{Radiometric (Emanation) Measurement Method}

The determination of the volumetric activity of radon was carried out using a measuring complex for monitoring radon, thoron and their daughter products "Alfarad plus" (NPP "Doza", Moscow, Russia). The measurement geometry was a 5-L plastic cylinder (counting sample).

The measurement of the volumetric activity of ${ }^{222} \mathrm{Rn}$ using this measuring instrument is based on the electrostatic deposition of charged ions ${ }^{218} \mathrm{Po}(\mathrm{RaA})$ from an air sample onto the surface of a semiconductor detector. Electrical impulses generated under the influence of alpha particles on the detector are amplified by a charge-sensitive preamplifier, fed to the input of the converter and then processed by the built-in single-board PC computer. The volumetric activity of ${ }^{222} \mathrm{Rn}$ is determined by the number of registered alpha particles during the decay of $\mathrm{RaA}$ atoms deposited on the detector [27]. 


\subsection{Calculation Methods for Assessing the Coefficient of Emanation}

The emanation coefficient of radon was determined by two methods: the gammaspectrometric and radiometric (emanation) methods.

First the radionuclide ${ }^{226} \mathrm{Ra}$ was measured using a gamma spectrometer. The method consists of measuring the gamma activity of samples at various intervals after they are placed in a hermetically sealed container. In this experiment, counting samples were prepared in the form of a crushed sample with a grain size of less than $0.5 \mathrm{~mm}$ in a 1-L Marinelli vessel.

Samples were measured daily for 21 days after they were sealed in the Marinelli vessel. Based on the results of these measurements, the following were determined: the activity of ${ }^{226} \mathrm{Ra}$, without taking into account the accumulation of its decay products; the activity of ${ }^{226} \mathrm{Ra}$, taking into account the accumulation of the daughter products of its decay (DPR); the emanation coefficient; and the period during which the DPR of ${ }^{226} \mathrm{Ra}$ enter a state of radioactive equilibrium. After the experiment, the counting sample was depressurized, and after 1-2 days, the specific activity of ${ }^{226} \mathrm{Ra}$ was measured again.

Based on the results of the experiment, the emanation coefficient of ${ }^{222} \mathrm{Rn}$ (its free state) was determined using the following formula:

$$
K_{R n}=\left(1-\frac{A_{226_{R a}}(\text { non }- \text { equilibrium })}{A_{226_{R a}}(\text { equilibrium })}\right) \times 100
$$

where $A_{226 R a}$ (non-equilibrium) is the activity of ${ }^{226} \mathrm{Ra}$ (in a nonequilibrium state), determined as the average value of the results of the first and last measurements (unsealed), $\mathrm{Bq} \cdot \mathrm{kg}^{-1}$; and $A_{226 R a}$ (equilibrium) is the specific activity of ${ }^{226} \mathrm{Ra}$ (in an equilibrium state), determined as the average value of the results of the last 5 measurements in a sealed state, $\mathrm{Bq} \cdot \mathrm{kg}^{-1}$.

At the second stage, rock samples were pre-dried at a temperature of $40{ }^{\circ} \mathrm{C}$ for at least $24 \mathrm{~h}$. Then the samples were sealed in plastic cylinders with a volume of $5 \mathrm{~L}$ for a period of at least 21 days, and using a radon radiometer, the volumetric activity of ${ }^{222} \mathrm{Rn}$ in the airspace of this cylinder was determined. To prevent the leakage of radon, the joints between each component of the apparatus were sealed with silicone rubber and glycerin prior to experimentation. This stage was necessary to assess the comparability with the results of gamma-spectrometric measurements and calculations of the level of radon production, as well as to confirm the fact of the release of ${ }^{222} \mathrm{Rn}$ from rocks in quantities corresponding to its free state.

The volumetric activity of ${ }^{222} \mathrm{Rn}$ in a cylinder at this stage in the airspace of this cylinder was calculated according to the following formula:

$$
A_{\text {Rn_container }}=\left(\frac{A_{R_{\text {volume }}}}{2000}\right) \times\left(1+\frac{V_{\text {chamber }}}{V_{\text {container }}}\right)
$$

where $A_{R n \_c o n t a i n e r}$ is the activity of ${ }^{222} \mathrm{Rn}$ in the free volume of the plastic container, $\mathrm{Bq} /$ container; $A_{R n \_ \text {volume }}$ is the volumetric activity of ${ }^{222} \mathrm{Rn}$, calculated from the results of measurements of the counting sample using a radon radiometer (in this case, the method was used for a geometry of a plastic vessel with a volume of $1 \mathrm{~L}), \mathrm{Bq} \cdot \mathrm{m}^{-3} ; V_{\text {container }}$ is the free volume of a plastic container after filling it with a rock sample, 1 ; and $V_{\text {chamber }}$ is the volume of the chamber of the radon radiometer, 1 .

According to the results of measurements at the second stage, the emanation coefficient of ${ }^{222} \mathrm{Rn}$ (its free state) was determined according to the following formula:

$$
K_{R n}=\frac{A_{222_{R n}} \times V}{\left(1-e^{-\left(\lambda-\lambda_{l}\right) t}\right) \times M \times A_{226_{R a}}}
$$

where $K_{R n}$ is the coefficient of radon emanation; $A_{222 R n}$ is the volumetric activity of radon in a free state in a sealed container, $\mathrm{Bq} \cdot \mathrm{m}^{-3} ; V$ is the free volume of the container, $\mathrm{m}^{3}$; 
$\lambda=2.1 \times 10^{-6} \mathrm{~s}^{-1}$ is the constant of radon decay; $\lambda l$ is the coefficient of radon leakage under the conditions of the experiment; $M$ is the total mass of the sample in the container; $t$ is the time of sealing of the counting sample; and $A_{226 R a}$ is the activity of ${ }^{226} \mathrm{Ra}$ in a counting sample, $\mathrm{Bq} \cdot \mathrm{kg}^{-1}$.

\subsection{Calculation of Radon Production Rate}

We also calculated the radon production rate, $P\left(\mathrm{~Bq} \cdot \mathrm{m}^{-3} \cdot \mathrm{h}^{-1}\right)$, using the following formula $[28,29]$ :

$$
P=\lambda K_{R n} A_{226_{R a}} \rho_{b}
$$

where $\lambda$ is the decay constant for radon $\left(2 \cdot 1 \cdot 10^{-6} \mathrm{~s}^{-1}\right)$ and $\rho_{\mathrm{b}}$ is the bulk density, $\mathrm{kg} \cdot \mathrm{m}^{-3}$.

\subsection{Assessment of Radon Leakage}

One of the important values of the uncertainty of measurements of radon activity in our experiment is the parameter of radon leakage from the container [23,30]. The estimation of the radon leakage parameter was carried out in the same geometry as the main experiment to determine the emanation coefficient. Two plastic containers with a volume of $5 \mathrm{~L}$ were connected through one hole with a valve. A source of radionuclide ${ }^{226} \mathrm{Ra}$ with high activity was placed in one container. The "inlet" and "outlet" fittings were located on the second container. A system of two containers through fittings was connected into one complex with a radon radiometer, an air blower and a dryer.

For the first stage, the experiment was carried out without a valve. The ${ }^{226} \mathrm{Ra}$ source was placed in container 1 for two weeks. ${ }^{222} \mathrm{Rn}$ formed as a result of the decay of ${ }^{226} \mathrm{Ra}$ was distributed in a system of two containers.

For the second stage, the opening connecting the two containers was closed with a valve, after which the first container with the ${ }^{226}$ Ra source was removed. Then a series of measurements of the volumetric activity of radon in the second container was carried out for 10 days every day. Based on the measurement results, the parameter of radon leakage, $\lambda_{1}$, was determined in a plastic container using the following formula [30]:

$$
A_{t}=A_{0} \times e^{-\left(\lambda+\lambda_{l}\right) t}
$$

where $\lambda$ is the decay constant of radon. The experimental facility for assessing radon leakage is shown in Figure 2.

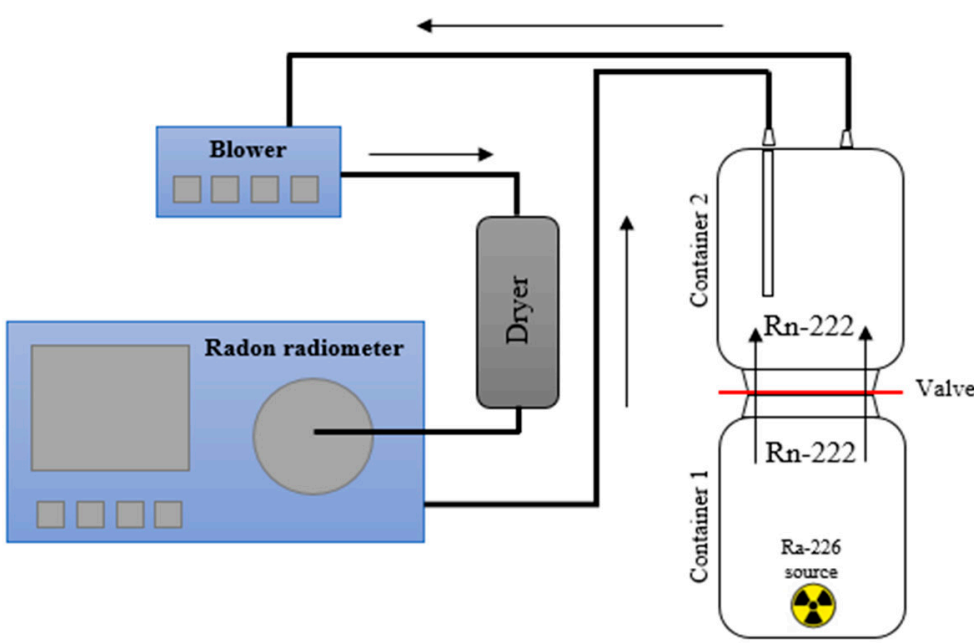

Figure 2. Experimental facility for assessing radon leakage.

\subsection{Assessment of Density and Porosity Parameters}

The determination of the parameters of porosity and the average (bulk) and true density of the selected samples was carried out according to the methods below, based 
on the works $[29,31]$. Average (bulk) density was used as a physical quantity determined by the ratio of the mass of the material to the entire volume it occupies, including pores and voids. True density is related to the densities of the minerals in the sample and their relative abundances.

\subsubsection{Assessment of Average (Bulk) Density}

The average density of the rock sample was determined by coating it with paraffin about $1 \mathrm{~mm}$ thick. For this, the sample, dried to constant weight, was immersed in heated paraffin and cooled in air. If bubbles or damage were found during cooling on the paraffin film, they were smoothed out using a hot metal plate, knife or wire.

The prepared sample was weighed. Then, weighing was carried out on a hydrostatic balance.

The average density of waxed rock samples of various shapes, $\rho k 1\left(\mathrm{~g} / \mathrm{cm}^{3}\right)$, was determined by the formula:

$$
\rho_{k 1}=\frac{m}{\frac{m_{1}^{\prime}-m_{2}^{\prime}}{\rho_{w}}-\frac{m_{1}^{\prime}-m}{\rho_{p}}}
$$

where $m$ is the dry weight of the sample, $g ; m^{\prime}{ }_{1}$ is the mass of the waxed sample in air, $g$; $m^{\prime}{ }_{2}$ is the mass of the waxed sample in water, $\rho_{w}$ is the density of water, taken to be equal to $1 \mathrm{~g} \cdot \mathrm{cm}^{-3}$; and $\rho_{p}$ is the density of paraffin (can be taken to be equal to $0.93 \mathrm{~g} \cdot \mathrm{cm}^{-3}$ ).

The result was calculated as the arithmetic mean of the test results of five rock samples.

\subsubsection{Assessment of True Density}

Test Preparation

Samples, on which the average density was determined, were used for testing. Each marked sample was cleaned to remove dust with a brush, ground to a grain size of $5 \mathrm{~mm}$ and then mixed. Then, the sample was reduced by quartering to $150 \mathrm{~g}$. Then, this sample was again ground to a grain size of less than $1.25 \mathrm{~mm}$, mixed and reduced to $30 \mathrm{~g}$. The prepared sample was ground into powder in a porcelain mortar, poured into a weighing glass or into a porcelain cup, dried to constant weight and cooled to room temperature in a desiccator over concentrated sulfuric acid or anhydrous calcium chloride, after which two portions of $10 \mathrm{~g}$ each were weighed.

\section{Testing}

Each sample was poured into a clean dried pycnometer, and distilled water was poured in such an amount that the pycnometer was filled to no more than half its volume. The pycnometer was placed in a slightly inclined position in a sand or water bath and its contents were boiled for 15-20 min to remove air bubbles. After removing air, the pycnometer was wiped off, cooled to room temperature, refilled to the mark with distilled water and weighed. The pycnometer was freed from the contents, washed, filled to the mark with distilled water at room temperature and weighed again.

Calculation of test results:

The true density $\rho_{\mathrm{w}}, \mathrm{g} \cdot \mathrm{cm}^{-3}$, was calculated by the formula:

$$
\rho=\frac{m \rho_{w}}{m+m_{1}-m_{2}}
$$

where $m$ is the weight of the sample of powder dried to constant weight, $g ; \rho_{w}$ is the density of water, taken to be equal to $1 \mathrm{~g} \cdot \mathrm{cm}^{-3} ; m_{1}$ is the mass of the pycnometer with distilled water, $\mathrm{g}$; and $m_{2}$ is the mass of the pycnometer with a sample and distilled water after removing air bubbles, $\mathrm{g}$.

The result was calculated as the arithmetic mean of two parallel tests. 


\subsubsection{Porosity Assessment}

The porosity of the rock samples, $\phi, \%$, was determined by a calculation based on the preset values of the true and average density, using the formula:

$$
\varphi=\left(1-\frac{\rho_{k}}{\rho}\right) \times 100
$$

where $\rho_{k}$ is the average density of the rock, $\mathrm{g} \cdot \mathrm{cm}^{-3} ; \rho$ is the true density of the rock, $\mathrm{g} \cdot \mathrm{cm}^{-3}$.

\section{Results and Discussion}

Table 1 shows the general characteristics of the samples under study. Depending on the facies they belong to, the samples of the studied rocks are subdivided into the following types: overlying deposits of Quaternary $(\mathrm{Q})$ and Carboniferous $\left(\mathrm{C}_{2}\right)$ age, enclosing rocks of the near-pipe space $\left(\mathrm{V}_{2}\right)$, tuffaceous-sedimentary rocks of the crater facies $\left(\mathrm{iD}_{3}-\mathrm{C}_{2}\right)$ and kimberlite vents $\left(\mathrm{iD}_{3}-\mathrm{C}_{2}\right)$.

Table 1. General characteristics of the investigated samples.

\begin{tabular}{|c|c|c|c|}
\hline & ID Sample & Rock Type & Geological Age \\
\hline \multicolumn{4}{|c|}{ Overlying Rocks } \\
\hline 1 & 7CA_13 & Moraine sand and gravel & Q \\
\hline 2 & GGS-2-10_1_2 & Sandstone & $\mathrm{C}_{2}$ \\
\hline 3 & GGS_2_10_20_5 & Sandstone & $\mathrm{C}_{2}$ \\
\hline 4 & GGS_2_10_30_0 & Sandstone & $\mathrm{C}_{2}$ \\
\hline 5 & GGS_2_10_54_1 & Sandstone, siltstone & $\mathrm{C}_{2}$ \\
\hline \multicolumn{4}{|c|}{ Enclosing Rocks of the Near-Pipe Space } \\
\hline 6 & 16CA_13 & Siltstone & $\mathrm{V}_{2}$ \\
\hline 7 & 18CA_13 & Siltstone & $\mathrm{V}_{2}$ \\
\hline 8 & CA_5_16 & Sandstone & $\mathrm{V}_{2}$ \\
\hline 9 & CA_13_16 & Sandstone & $\mathrm{V}_{2}$ \\
\hline 10 & CA_14_16 & Sandstone & $\mathrm{V}_{2}$ \\
\hline 11 & CA_21_16 & Sandstone & $\mathrm{V}_{2}$ \\
\hline 12 & CA_6_16 & Sandstone & $\mathrm{V}_{2}$ \\
\hline 13 & CA_7_16 & Sandstone & $\mathrm{V}_{2}$ \\
\hline 14 & CA_8_16 & Sandstone & $\mathrm{V}_{2}$ \\
\hline 15 & CA_19_16 & Sandstone & $\mathrm{V}_{2}$ \\
\hline 16 & 24CA_13 & Sandstone & $\mathrm{V}_{2}$ \\
\hline 17 & 40CA_13 & Sandstone & $\mathrm{V}_{2}$ \\
\hline 18 & 11CA_13 & Siltstone & $\mathrm{V}_{2}$ \\
\hline 19 & 12CA_13 & Siltstone & $\mathrm{V}_{2}$ \\
\hline 20 & 21CA_13 & Siltstone & $\mathrm{V}_{2}$ \\
\hline \multicolumn{4}{|c|}{ Tuffaceous Sedimentary Rocks of the Peripheral Parts of the Crater } \\
\hline 21 & 30CA_13 & Tuffite & $\mathrm{iD}_{3}-\mathrm{C}_{2}$ \\
\hline 22 & 31CA_13 & Tuffite & $\mathrm{iD}_{3}-\mathrm{C}_{2}$ \\
\hline 23 & CA_10_16 & Tuffite & $\mathrm{iD}_{3}-\mathrm{C}_{2}$ \\
\hline 24 & CA_12_16 & Tuffite & $\mathrm{iD}_{3}-\mathrm{C}_{2}$ \\
\hline 25 & 33CA_13 & Tuff & $\mathrm{iD}_{3}-\mathrm{C}_{2}$ \\
\hline \multicolumn{4}{|c|}{ Vent Facies Kimberlites } \\
\hline 26 & CA_16_16 & Autolithic breccia & $\mathrm{iD}_{3}-\mathrm{C}_{2}$ \\
\hline 27 & CA_17_16 & Autolithic breccia & $\mathrm{iD}_{3}-\mathrm{C}_{2}$ \\
\hline 28 & 2009_477 & Autolithic breccia & $\mathrm{iD}_{3}-\mathrm{C}_{2}$ \\
\hline 29 & 2013_262 & Autolithic breccia & $\mathrm{iD}_{3}-\mathrm{C}_{2}$ \\
\hline 30 & 37CA_13 & Autolithic breccia & $\mathrm{iD}_{3}-\mathrm{C}_{2}$ \\
\hline
\end{tabular}




\subsection{Estimation of the Parameter of Radon Leakage from a Counting Sample}

The decrease in radon activity in the experimental model is shown in the Figure 3. This process occurs due to radioactive decay, as well as radon leakage through the container. The average value of the level of radon leakage was $9.02 \pm 0.28 \% \cdot 10^{-7} \mathrm{~s}^{-1}$.

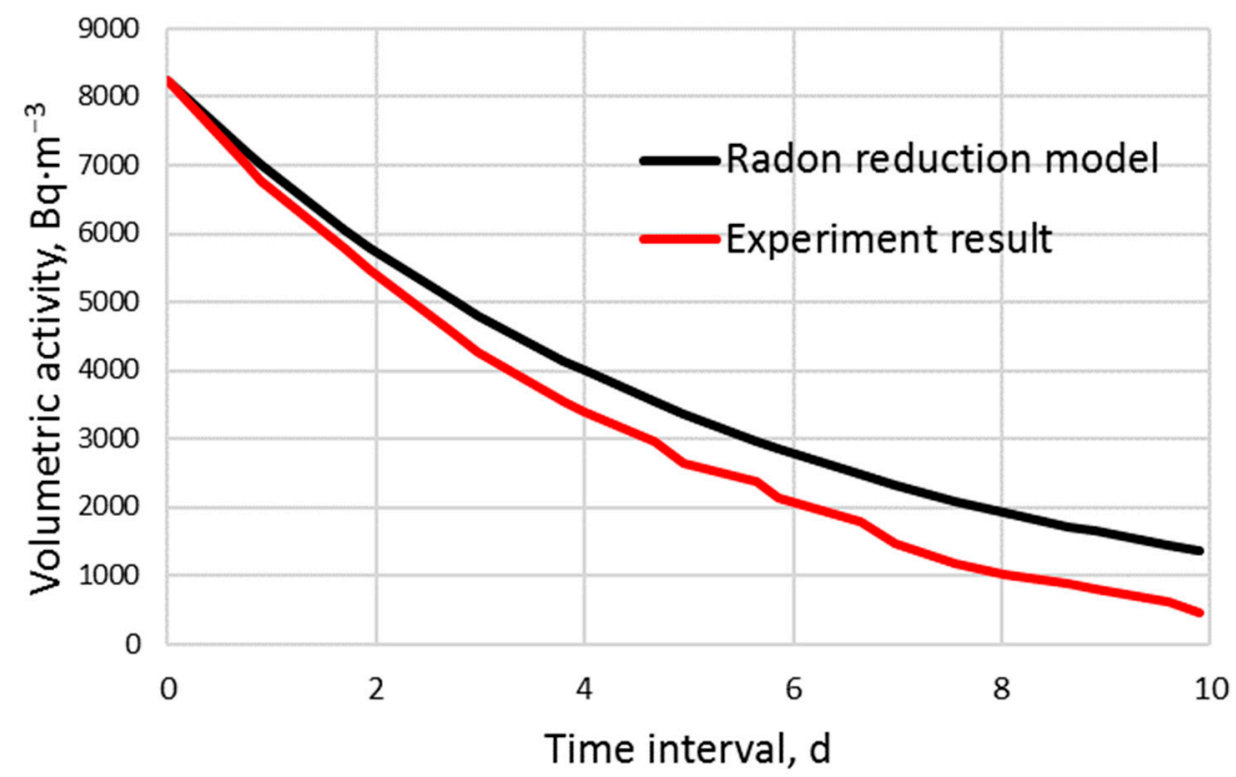

Figure 3. Radon leakage parameter assessment results.

\subsection{Results of Measurements of Radiation and Physical Parameters}

As mentioned earlier, in the first stage, the activity of ${ }^{226} \mathrm{Ra}$ was measured daily for 21 days. Based on the results of these measurements, the following were determined: the activity of ${ }^{226} \mathrm{Ra}$, without taking into account the accumulation of its decay products; the activity of ${ }^{226} \mathrm{Ra}$, taking into account the accumulation of the daughter products of its decay; the percentage of radon accumulation (in the "free" state); and the period for which the daughter decay products of ${ }^{226} \mathrm{Ra}$ enter the state of radioactive equilibrium. After the experiment, the counting sample was depressurized, and after 1-2 days, the specific activity of ${ }^{226} \mathrm{Ra}$ was measured again.

To establish the equilibrium of all members of the ${ }^{226}$ Ra series in the samples of the studied rocks, a time interval from 5 to 10 days is sufficient (Figure 4). When carrying out further studies with rocks of other types, we consider it possible to reduce the measurement period to 15 days.

The emanation coefficient was calculated using two methods: gamma-spectrometric and radiometric (emanation). The coefficient of variation between the results of both methods did not exceed $5-10 \%$. So herein when the emanation coefficient is mentioned it refers to the one calculated only by the gamma spectrometric method.

In general, the research results are presented in Table 2, in which the following designations are used: $\mathrm{A}_{\mathrm{Ra} 226}$ - specific activity of ${ }^{226} \mathrm{Ra}$ under sealing conditions; $\mathrm{K}_{\text {emanation }}$ coefficient of emanation; $\mathrm{AV}_{\text {dens }}$ - average density; $\mathrm{TR}_{\text {dens }}$ - true density; Porosity - porosity. Additionally, these designations are used later in the text of the article. In expanded form the results of the study of radiation and physical parameters are shown in Table A1, Appendix A. 


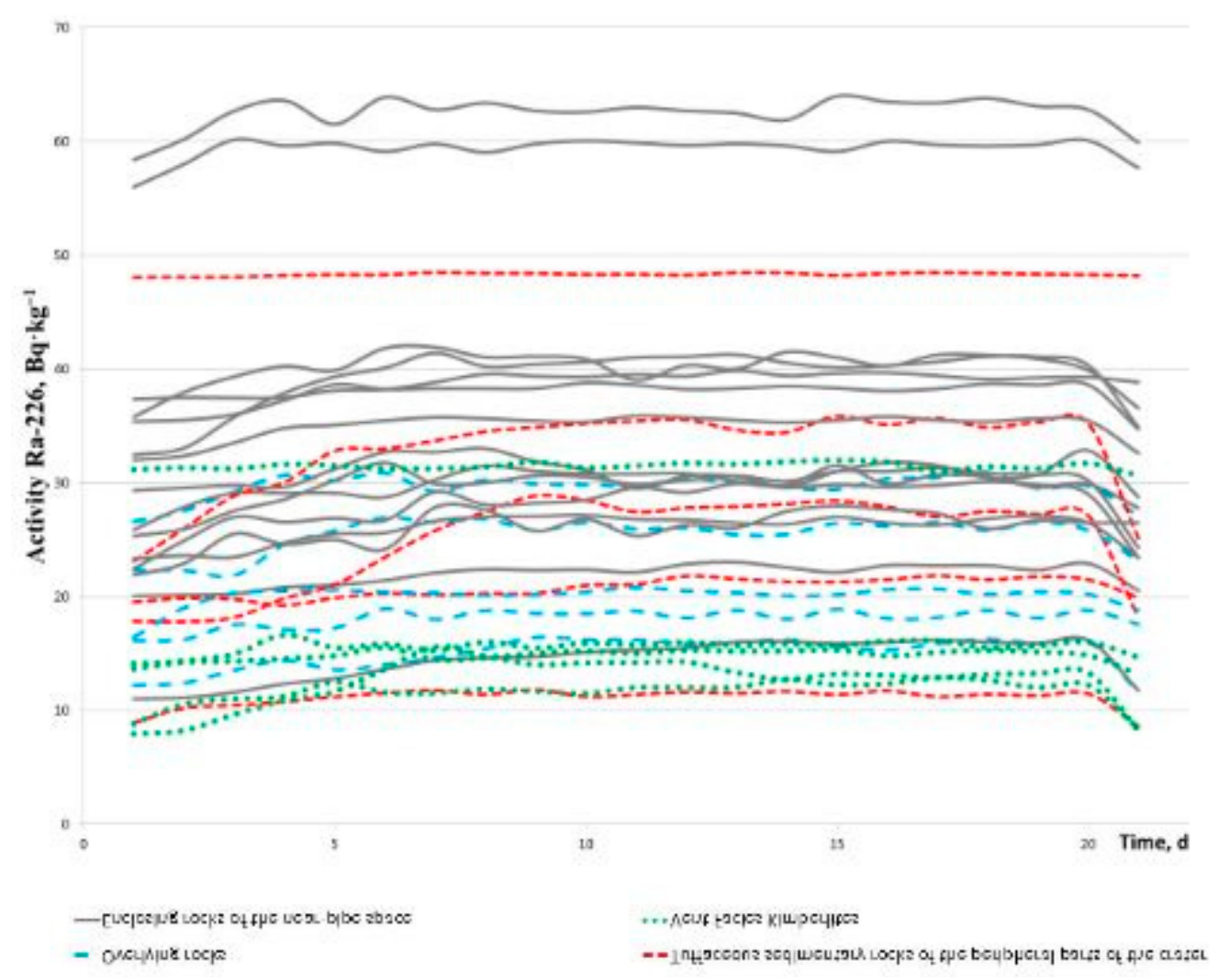

Figure 4. The nature of the distribution of the activity of ${ }^{226} \mathrm{Ra}$ in time after sealing.

Table 2. Results of measurements of radiation and physical characteristics of samples.

\begin{tabular}{|c|c|c|c|c|c|c|c|c|c|c|}
\hline & \multicolumn{10}{|c|}{ Radiation and Physical Characteristics } \\
\hline & \multicolumn{2}{|c|}{$A_{\text {Ra226 }}$} & \multicolumn{2}{|c|}{$K_{\text {emanation }}$} & \multicolumn{2}{|c|}{$\mathbf{A V}_{\text {dens }}$} & \multicolumn{2}{|c|}{$\mathbf{T R}_{\text {dens }}$} & \multicolumn{2}{|c|}{ Porosity } \\
\hline & Range & Mean & Range & Mean & Range & Mean & Range & Mean & Range & Mean \\
\hline Overlapping Rocks & $15.88-30.21$ & 22.19 & $11.09-24.91$ & 17.41 & $1.83-2.03$ & 1.93 & $2.38-2.94$ & 2.54 & $18.47-32.65$ & 23.77 \\
\hline Kimberlites & $12.42-31.46$ & 17.59 & $1.76-10.67$ & 7.14 & $1.74-2.35$ & 2.06 & $1.83-2.37$ & 2.11 & $0.46-4.92$ & 2.39 \\
\hline Host Rocks & $16.05-63.32$ & 35.52 & $6.19-29.13$ & 13.94 & $1.47-2.19$ & 1.89 & $2.06-2.7$ & 2.42 & $4.72-40.96$ & 21.11 \\
\hline $\begin{array}{c}\text { Tuffaceous } \\
\text { Sedimentary Rocks }\end{array}$ & $11.45-48.4$ & 28.81 & $9.82-34.13$ & 22.34 & $1.36-1.90$ & 1.73 & $2.12-2.54$ & 2.28 & $13.21-36.74$ & 24.04 \\
\hline
\end{tabular}

We have identified a wide range in the ${ }^{222} \mathrm{Rn}$ emanation coefficient in the studied rock samples from 3 to $40 \%$. The kimberlites of the vent facies, represented by autolithic breccias, are characterized by low values of the emanation coefficient, in the range from 1 to $8 \%$. In only one case, the value of the emanation coefficient exceeded $10 \%$. Kimberlites were also characterized by a low porosity from 0.46 to $4.91 \%$, which agrees with previously obtained results for pipes of the Arkhangelsk diamondiferous province [32]. At the same time, kimberlite pipes in Yakutia have been characterized by a wider range of porosity variation from 3.6 to $12.9 \%$ and in rare cases exceeding $20 \%$ [33,34]. Vent kimberlites are characterized by the lowest activity of ${ }^{226} \mathrm{Ra}$ among the studied types of rocks, varying from 12.42-15.89 Bq. $\mathrm{kg}^{-1}$ (including sealing), with the exception of one sample, in which the specific activity of ${ }^{226} \mathrm{Ra}$ was much higher $31.46 \mathrm{~Bq} \cdot \mathrm{kg}^{-1}$ (sample ID 37CA-13). It is known that among the magmatic formations, kimberlites are characterized minimal content of radioactive elements [35]. In addition, the kimberlites of the pipes of the Zolotitsky field have been characterized by an extremely low average concentration of uranium, $0.67 \mathrm{mg} \cdot \mathrm{kg}^{-1}$ [19], which, in terms of the activity of ${ }^{226} \mathrm{Ra}$ under conditions of radioactive equilibrium in the uranium-238 chain, does not exceed $10 \mathrm{~Bq} \cdot \mathrm{kg}^{-1}$.

Tuffaceous-sedimentary rocks were distinguished by a wider range of radiation and physical parameters. The activity of ${ }^{226} \mathrm{Ra}$ in these rocks varies from 11.45 to $48.40 \mathrm{~Bq} \cdot \mathrm{kg}^{-1}$, 
the emanation coefficient from 9.82 to $34.13 \%$ and porosity from 13.20 to $36.74 \%$. However, a different picture was observed in the distribution of the studied parameters in the host Vendian and overlying Quaternary and Carboniferous rocks. Most of these rocks were characterized by significant porosity (up to $41 \%$ ) which are in good agreement with the data given in [32] concerning the study of the host rocks of the Arkhangelsk diamondiferous province (from 8 to $40 \%$ ). The host rocks are distinguished by a high level of specific activity of ${ }^{226} \mathrm{Ra}$ - up to $63.32 \mathrm{~Bq} \cdot \mathrm{kg}^{-1}$ and the overlying rocks have a high level of the emanation coefficient (up to $28 \%$ ) (Figure 5).

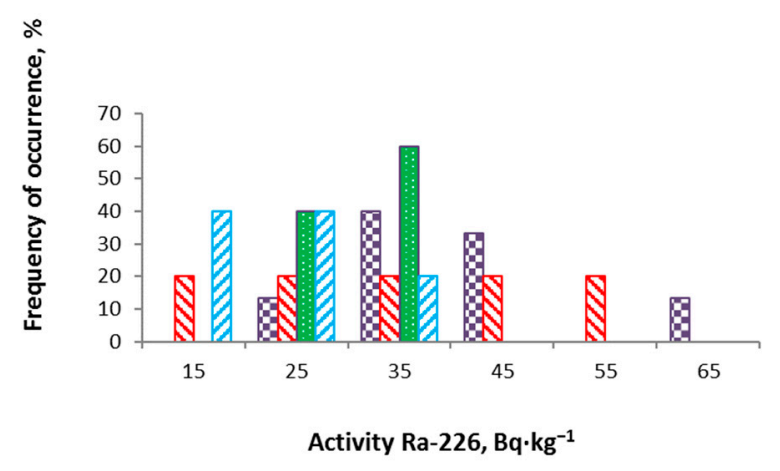

(a)

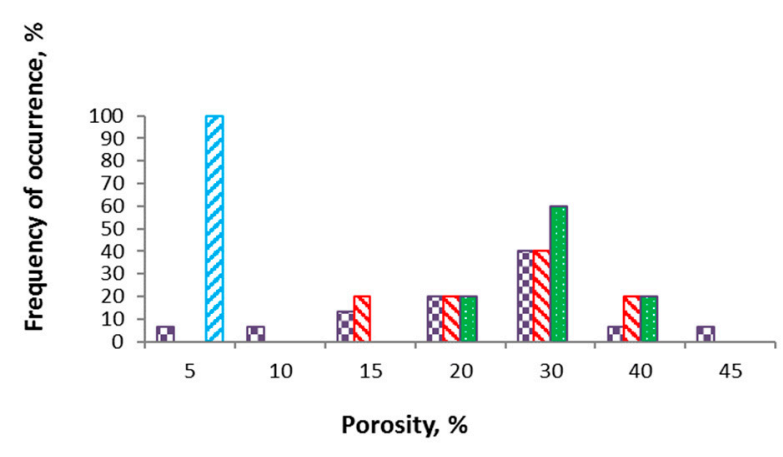

(c)

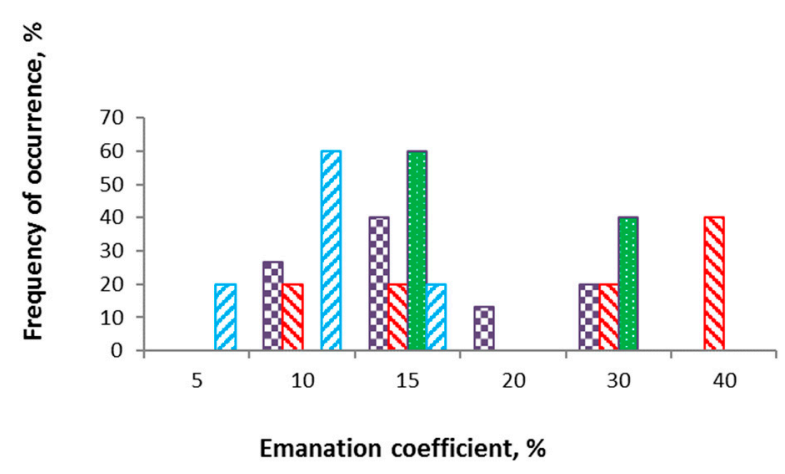

(b)
곡 Host rocks

$\mathbb{N}$ Tuffaceous sedimentary rocks

\section{Kimberlites}

Figure 5. Histogram of radium activity (a), emanation coefficient (b) and porosity (c) for the studied types of rocks.

The rate of radon production was calculated for the different types of rocks (Table 3). This parameter is one of the most important for assessing radon in its free state.

Table 3. Radon production rate for the studied types of rocks.

\begin{tabular}{ccc}
\hline & Radon Production Rate, $\mathbf{B q} \cdot \mathbf{m}^{-\mathbf{3}} \cdot \mathbf{h}^{-\mathbf{1}}$ & \\
\hline & Range & Mean \\
\hline Overlapping Rocks & $38.88-59.12$ & 52.47 \\
\hline Kimberlites & $9.84-18.96$ & 16.15 \\
\hline Host rocks & $37.19-132.03$ & 63.88 \\
\hline Tuffaceous Sedimentary Rocks & $33.97-139.57$ & 75.39 \\
\hline
\end{tabular}


The minimum level of radon production, from 9.84 to $18.96 \mathrm{~Bq} \cdot \mathrm{m}^{-3} \cdot \mathrm{h}^{-1}$ (Table 3) is characteristic of kimberlites of the vent facies. Considering the high values of the specific activity of radium, the emanation coefficient, the level of radon production and porosity, the enclosing rocks of the near-pipe space stand out among the other types. In the Vendian host rocks a number of mineralogical, structural and geochemical features were found. Postmagmatic endogenous bleaching associated with the influence of kimberlites was found in the host red rocks of the Vendian [21,36-41]. The zones of bleaching occurred at the contact with magmatic bodies and in tectonic faults were formed as a result of the action of reducing fluids [42]. These rocks with vein bleaching clarification are characterized by an increased content of uranium, thorium and potassium, and they are also characterized by geochemical anomalies, specific mineralogical associations and stable isotope anomalies $[21,22,40]$. These rocks with vein endogenous bleaching are characterized by high content of $\mathrm{K}, \mathrm{Fe}, \mathrm{Rb}, \mathrm{Zn}, \mathrm{Sr}, \mathrm{Ni}$ and depleted (light) isotopic composition of calcite carbon $\left(\delta^{13} \mathrm{C}-4.9\right.$ and $-5.5 \%$ ) Among specific mineralogical associations the saponite and minerals of smectite group (including montmorillonite and beidellite) are observed [37,40-43]. The contacts of kimberlites and host rocks have local tectonic elements: zones of mylonites, steep fractures and low-amplitude thrusts [21,40,43-47]. The abundance of fracture zones in the near-pipe space of kimberlite bodies is associated with the process of diatreme formation, which influenced the tectonic structure of the adjacent sediment, resulting in the formation of a system of fractures of various types [48]. The occurrence of zones of fracturing and faults is associated with the formation of diatremes as a result of the significant mechanical effect of penetrating gases and melts on the host rocks $[49,50]$. As a result, a system of radial and concentric zones of fracturing and faults with crushing and the vertical movement of blocks of enclosing rocks has arisen in the near-pipe space [51]. The impact of kimberlites on the Vendian rocks, which led to the formation of fault zones in the near-pipe space, increased the fracturing and various mineralogical and geochemical changes, influencing the radiation parameters of the host rock. Enrichment with uranium (radium) and the increased fracturing of the near-pipe space created conditions for the production and advection of radon through the host rock mass. As a result, in the soil horizons above the kimberlite bodies of the Lomonosov diamond deposit, an increased volumetric activity of radon can be observed, several times higher than the background values [20,52]. In the course of this study, we found that the main source of radon observed in the soil air above kimberlite pipes is the enclosing Vendian rocks of the near-pipe space.

To understand the relationship between the studied radiation and physical parameters, a statistical analysis of the data was performed.

\subsection{Statistical Analysis}

To study the features of radon emanation in rocks, a correlation analysis of the main radiation and physical parameters of the samples was performed (Table 4). The following parameter was also added to the correlation matrix: $A_{R n 222}$, the volumetric activity of radon in the container, $\mathrm{Bq} \cdot \mathrm{m}^{-3}$. The values of this parameter were obtained as a result of experimental work on the accumulation of radon in a sealed container with test samples.

Table 4. Correlation matrix from the studied parameters of the radon emanation.

\begin{tabular}{ccccccc}
\hline & $\mathbf{A}_{\text {Ra226 }}$ & $\mathbf{K}_{\text {emanation }}$ & $\mathbf{A}_{\text {Rn222 }}$ & $\mathbf{A V}_{\text {dens }}$ & TR $_{\text {dens }}$ & Porosity \\
\hline $\mathrm{A}_{\text {Ra226 }}$ & 1 & & & & & \\
$\mathrm{~K}_{\text {emanation }}$ & -0.277 & 1 & & & & \\
$\mathrm{~A}_{\text {Rn222 }}$ & 0.350 & 0.709 & 1 & & & \\
$\mathrm{AV}_{\text {dens }}$ & 0.054 & -0.666 & -0.531 & 1 & & \\
$\mathrm{TR}_{\text {dens }}$ & 0.092 & 0.294 & 0.335 & 0.155 & 1 & \\
Porosity & 0.043 & 0.753 & 0.691 & -0.648 & 0.646 & 1 \\
\hline
\end{tabular}

Number of samples $=30$. Correlation is significant at the 0.01 level. 
A significant correlation is observed in rocks for Kemanation- $A_{R n 222}(r=0.709)$, $\mathrm{K}_{\text {emanation }}-\mathrm{AV}_{\text {dens }}(\mathrm{r}=-0.666), \mathrm{K}_{\text {emanation }}$-Porosity $(\mathrm{r}=0.753), \mathrm{A}_{\mathrm{Rn} 222}-\mathrm{AV}_{\text {dens }}(\mathrm{r}=-0.531)$, $\mathrm{A}_{\mathrm{Rn} 222}$-Porosity $(\mathrm{r}=0.691), \mathrm{AV}_{\text {dens }}$-Porosity $(\mathrm{r}=-0.648)$ and $\mathrm{TR}_{\text {dens }}$-Porosity $(\mathrm{r}=0.646)$. ${ }^{226} \mathrm{Ra}$ activity in rock samples has no significant correlations with any of the parameters suggesting that it is not the main parameter influencing the formation of a radon field. The lack of relationships between the content of ${ }^{226} \mathrm{Ra}$ and the volumetric activity of radon is probably due to the form of ${ }^{226} \mathrm{Ra}$ in the minerals that make up the rocks [30,53]. Radon formed in a solid can enter the surrounding space due to both radioactive recoil and diffusion. In the case of radioactive decay, radon atoms acquire a certain recoil energy, which they subsequently lose when moving. Some of the atoms remain in the solid phase making up so-called "bound radon". However, the recoil energy of about $86 \mathrm{keV}$ is enough to release atoms outside the crystal lattice, while forming free radon [24].

Taking the above into account, to characterize the territory of Arkhangelsk diamondiferous province according to the distribution of radon, it is advisable to use a complex of two parameters-the activity of ${ }^{226} \mathrm{Ra}$ in soils and rocks and their emanation coefficient.

As can be seen from the correlation data, the main factors in the formation of the radon field are the emanation coefficient $(\mathrm{r}=0.709)$ and the porosity of the rock $(\mathrm{r}=0.691)$. At the same time, an increase in porosity leads to an increase in the emanation coefficient $(r=0.753)$. There is a negative relationship between the average density and the volumetric activity of radon in a free state $(r=-0.531)$. This is due to the fact that the method for calculating the average density takes into account the presence of pores in the rock. At the same time, the true density is characterized by a weak effect on the emanation coefficient and the volumetric activity of radon.

Additional information for the interpretation of the obtained statistical data on rock samples is provided by the results of factor analysis (Table 5).

Table 5. Factor loadings matrix for dataset on the studied parameters of radon emanation.

\begin{tabular}{cccc}
\hline & & Factor & \\
\cline { 2 - 4 } Parameter & $\mathbf{1}$ & $\mathbf{2}$ & $\mathbf{3}$ \\
\hline A $_{\text {Ra226 }}$ & -0.040 & 0.036 & -0.256 \\
$\mathrm{~K}_{\text {emanation }}$ & 0.876 & 0.271 & 0.418 \\
A $_{\text {Rn222 }}$ & 0.776 & 0.288 & 0.028 \\
AV $_{\text {dens }}$ & -0.920 & 0.248 & 0.054 \\
TR dens & 0.071 & 0.992 & 0.036 \\
Porosity & 0.774 & 0.572 & 17.95 \\
\hline
\end{tabular}

On the diagram of factor loads (Figure 6), three groups of factors are distinguished, which determine the nature of the emanation of radon from rocks. The total variance for the three factors is $91.91 \%$.

The first factor, with a dispersion of $52.81 \%$, includes the radon emanation coefficient, the volumetric activity of radon in the counting sample and the porosity of the sample. This is due to the fact that these parameters are the main parameters in the process of forming a radon field. This conclusion was made in the conditions of the experiment and does not take into account other physical factors that can affect the behavior (gas permeability, humidity, temperature, pressure). The same parameters are involved in calculating the level of radon production.

The second factor, with a dispersion of $21.15 \%$, combines two parameters-true density and porosity. The relationship between these parameters is due to the fact that the porosity is a calculated value and is determined based on the density of the sample.

The third factor is represented by one parameter-the activity of radionuclide ${ }^{226} \mathrm{Ra}$. 
The weak determination of the second and third factors is probably associated with more complex interaction mechanisms during the formation of the radon field; to fully understand them, additional data are required to determine the geochemical and mineralogical compositions [14].

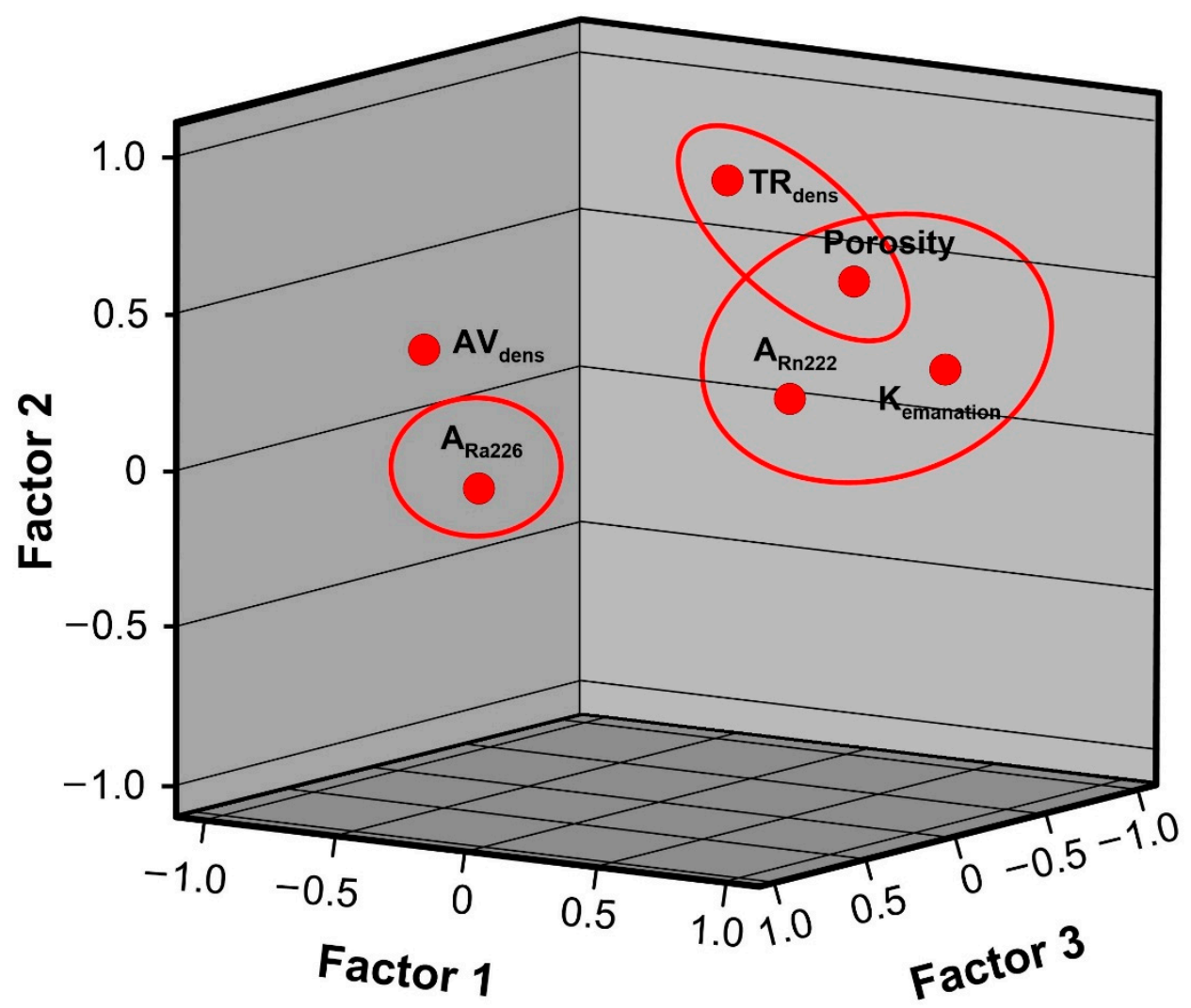

Figure 6. Plot of factor loadings for studied parameters of radon emanation.

Based on the results of measuring the volumetric activity of radon in a sealed container and calculating the level of radon production, we built a regression model (Figure 7), which is a linear function of the dependence of two parameters (dependent variable and regressor) and is characterized by regression coefficients (i.e., slope, coefficient of determination).

In our experiment, the regression model has the form $y=19.138 x-32.696$ and is characterized by a positive slope equal to 19.138 and a coefficient of determination $R^{2}=0.8786$. The positive slope indicates that with an increase in the level of radon production by 1 unit, the volumetric activity increases by $19.138 \mathrm{~Bq} \cdot \mathrm{m}^{-3}$. This value is theoretical and can vary depending on a number of parameters. For this model, it is calculated based on the results of the measurements of parameters. The value of the constant $\mathrm{a}=-32.696$ in this case is not taken into account, because under ideal conditions (for example, the absence of extraneous sources of radon) at a level of radon production $\mathrm{P}=0 \mathrm{~Bq} \cdot \mathrm{m}^{-3} \mathrm{~h}^{-1}$, the volumetric activity will also be equal to $0 \mathrm{~Bq} \cdot \mathrm{m}^{-3}$.

The coefficient of determination shows that the change in the volumetric activity of radon in the container (dependent variable) by $87.9 \%$ is described by the independent variable (regressor) - the level of radon production — which indicates a sufficient justification for choosing this model. This model more clearly predicts the distribution of radon based on the results of calculating the radon production rate. 


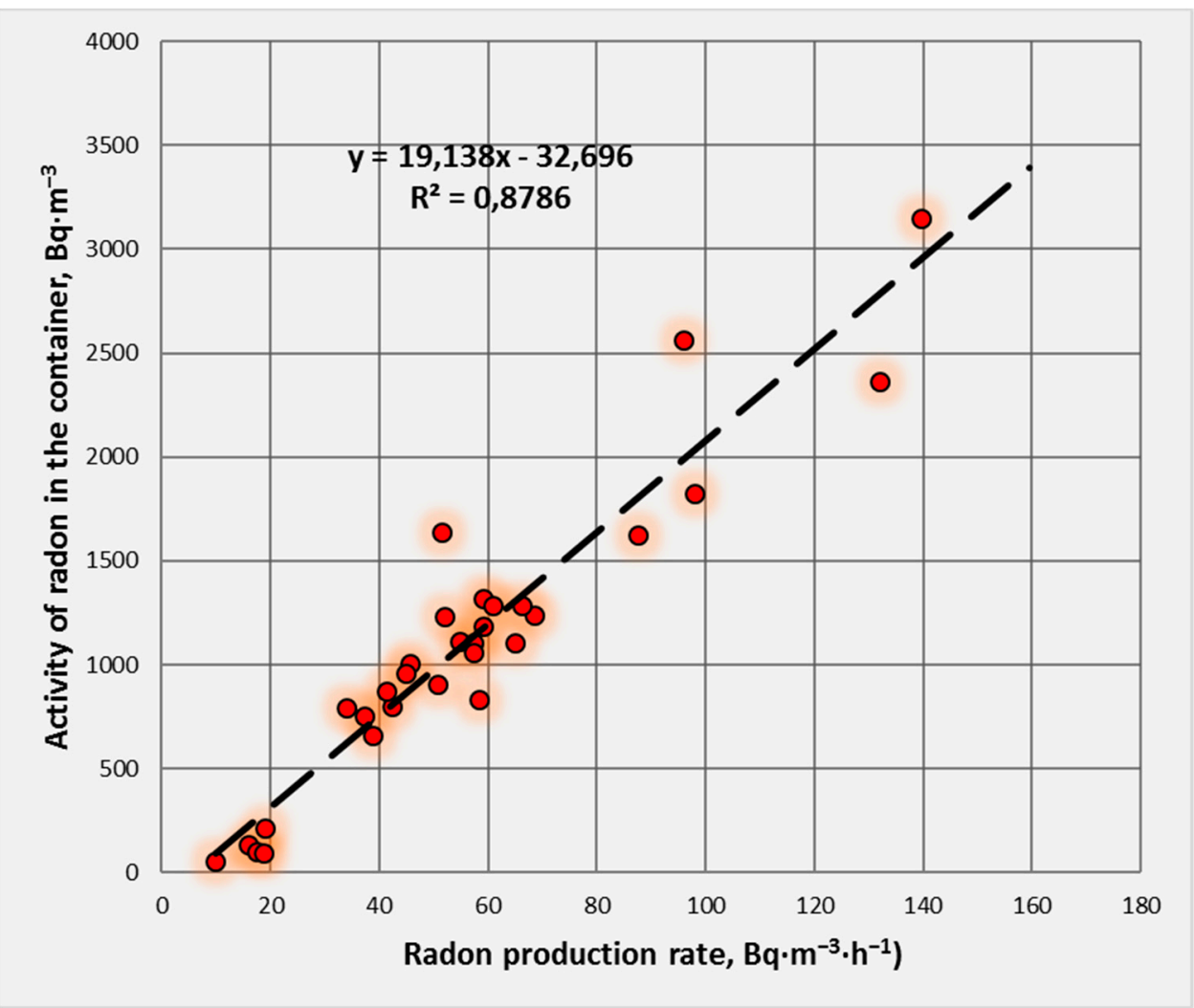

Figure 7. Regression model of the relationship between the volumetric activity of radon and the level of radon production.

\section{Conclusions}

Experimental studies were carried out to assess the main radiation and physical factors affecting the formation of the radon field over the kimberlite pipes of the Arkhangelsk diamondiferous province. For this purpose, samples of kimberlites and rocks were taken from the quarries of the Arkhangelskaya and Karpinsky-1 pipes of the Lomonosov diamond deposit. The samples were represented by the main types of rocks exposed by quarries to a depth of $186 \mathrm{~m}$ : overlying Quaternary $(\mathrm{Q})$ and Carboniferous rocks $\left(\mathrm{C}_{2}\right)$, host rocks of the Vendian $\left(\mathrm{V}_{2}\right)$, tuffaceous-sedimentary rocks of the crater $\left(\mathrm{iD}_{3}-\mathrm{C}_{2}\right)$ and kimberlites of the vent facies $\left(\mathrm{iD}_{3}-\mathrm{C}_{2}\right)$.

Radiation (activity of ${ }^{226} \mathrm{Ra}$, activity of ${ }^{222} \mathrm{Rn}$ in a free state, emanation coefficient, radon production rate) and physical (average and true density, porosity) parameters were determined.

Among the studied types of rocks, it was found that kimberlites of the vent facies are characterized by the lowest values of the emanation coefficient, porosity, specific activity of ${ }^{226} \mathrm{Ra}$ and the radon production rate. The lowest values of these parameters limit the formation of free radon in the pipe body.

The largest amount of radon in a free gas state has been produced by rocks of the near-pipe space, represented by the enclosing Vendian $V_{2}$ deposits and characterized by high values of the emanation coefficient, specific activity of radium, radon production rate and porosity. This is due to the structural and geological features of the near-pipe space, which has signs of the impact of kimberite magma on the host rocks: the development of fracturing as well as structural, mineralogical and geochemical changes. The overlying and tuffaceous-sedimentary rocks of the crater are characterized by intermediate values of the studied parameters.

This study advances the knowledge of using emanation methods for prospecting for kimberlite pipes in the territory of the Arkhangelsk diamondiferous province. 
Author Contributions: All authors contributed to the study conception and design. Conceptualization, validation, and writing-original draft preparation were performed by E.Y. and A.P. Methodology was performed by E.Y. and A.P. Formal analysis and investigation were performed by E.Y. and A.P. Writing-review and editing were performed by E.Y. and A.P. Funding acquisition were performed by E.Y. Project administration and resources were performed by E.Y. Supervision and visualization were performed by E.Y. All authors have read and agreed to the published version of the manuscript.

Funding: The reported study was funded by RFBR, project number 20-35-70060.

Institutional Review Board Statement: Not applicable.

Informed Consent Statement: Not applicable.

Data Availability Statement: The datasets presented in this study can be obtained upon request to the corresponding author.

Acknowledgments: The authors are grateful to the staff of the Laboratory of Environmental Radiology of N. Laverov Federal Center for Integrated Arctic Research for their invaluable help and support at all stages of the study.

Conflicts of Interest: The authors declare that they have no conflicts of interest. 


\section{Appendix A}

Table A1. Radiation and physical characteristics of studied rocks.

\begin{tabular}{|c|c|c|c|c|c|c|c|c|c|}
\hline \multirow[b]{2}{*}{ Sample ID } & \multicolumn{6}{|c|}{ Radiation Parameters } & \multicolumn{3}{|c|}{ Physical Parameters } \\
\hline & $\begin{array}{c}\text { Radium-226 Activity } \\
\text { (Unsealed Sample), } \\
\text { Bq.kg-1 }^{-1}\end{array}$ & $\begin{array}{l}\text { Radium-226 Activity } \\
\text { (Sealed Sample), } \\
\text { Bq.kg-1 }^{-1}\end{array}$ & $\begin{array}{l}\text { Radium-226 Activity (after } \\
\text { Opening the Sample), } \\
\text { Bq.kg }^{-1}\end{array}$ & $\begin{array}{c}\text { Emanation } \\
\text { Coefficient, } \%\end{array}$ & $\begin{array}{l}\text { Volumetric Activity of } \\
\text { Radon in the } \\
\text { Container, } \mathbf{B q} \cdot \mathbf{m}^{-3}\end{array}$ & $\begin{array}{l}\text { Radon Production } \\
\text { Rate }^{*}, \mathbf{B q} \cdot \mathbf{m}^{-3} \cdot \mathbf{h}^{-1}\end{array}$ & $\underset{\mathrm{g} \cdot \mathrm{cm}^{-3}}{\text { Average Density **, }}$ & $\begin{array}{c}\text { True Density **, } \\
\text { g. } \mathrm{cm}^{-3}\end{array}$ & Porosity ***, \% \\
\hline \multicolumn{10}{|c|}{ Overlying Rocks } \\
\hline GGS-2-10_1_2 & $22.33 \pm 4.69$ & $26.40 \pm 4.22$ & $23.17 \pm 4.40$ & $13.83 \pm 3.78$ & $1116 \pm 335$ & 54.64 & 1.98 & 2.94 & 32.65 \\
\hline GGS_2_10_20_5 & $16.12 \pm 3.71$ & $18.01 \pm 3.06$ & $17.57 \pm 4.57$ & $23.47 \pm 8.02$ & $1120 \pm 336$ & 59.12 & 1.85 & 2.39 & 22.59 \\
\hline GGS_2_10_30_0 & $12.21 \pm 3.42$ & $15.88 \pm 4.13$ & $11.64 \pm 3.38$ & $24.91 \pm 10.67$ & $834 \pm 250$ & 58.32 & 1.95 & 2.50 & 22.00 \\
\hline GGS_2_10_54_1 & $26.59 \pm 4.52$ & $30.21 \pm 4.53$ & $27.13 \pm 3.53$ & $11.09 \pm 2.42$ & $1637 \pm 491$ & 51.41 & 2.03 & 2.49 & 18.47 \\
\hline \multicolumn{10}{|c|}{ Enclosing Rocks of the Near-Pipe Space } \\
\hline 16CA_13 & $37.37 \pm 5.98$ & $39.34 \pm 5.51$ & $36.44 \pm 5.10$ & $6.19 \pm 1.35$ & $755 \pm 227$ & 37.19 & 2.02 & 2.12 & 4.72 \\
\hline CA_5_16 & $11.01 \pm 3.19$ & $16.05 \pm 3.85$ & $\begin{array}{l}11.74 \pm 3.29 \\
\end{array}$ & $29.13 \pm 11.82$ & $1235 \pm 371$ & 51.96 & 1.47 & 2.49 & 40.96 \\
\hline CA_13_16 & $22.44 \pm 4.94$ & $29.67 \pm 6.23$ & $23.42 \pm 5.15$ & $22.72 \pm 7.60$ & $1822 \pm 547$ & 97.85 & 1.92 & 2.66 & 27.82 \\
\hline CA_14_16 & $25.90 \pm 5.96$ & $30.73 \pm 4.30$ & $27.82 \pm 6.40$ & $12.60 \pm 3.73$ & $1105 \pm 332$ & 57.37 & 1.96 & 2.38 & 17.65 \\
\hline CA_21_16 & $56.01 \pm 8.96$ & $59.84 \pm 7.78$ & $55.69 \pm 6.13$ & $6.67 \pm 1.25$ & $1059 \pm 318$ & 57.33 & 1.90 & 2.62 & 27.48 \\
\hline CA_6_16 & $35.79 \pm 6.80$ & $40.69 \pm 6.10$ & $36.55 \pm 5.85$ & $11.11 \pm 2.68$ & $1186 \pm 356$ & 59.12 & 1.73 & 2.06 & 16.02 \\
\hline CA_7_16 & $21.90 \pm 4.16$ & $26.84 \pm 5.64$ & $23.51 \pm 4.70$ & $15.41 \pm 4.92$ & $1241 \pm 372$ & 68.48 & 2.19 & 2.55 & 14.12 \\
\hline CA_8_16 & $25.35 \pm 5.83$ & $30.82 \pm 4.93$ & $24.30 \pm 5.10$ & $19.45 \pm 5.65$ & $1624 \pm 487$ & 87.46 & 1.93 & 2.59 & 25.48 \\
\hline CA_19_16 & $28.33 \pm 6.80$ & $31.46 \pm 5.66$ & $27.75 \pm 5.27$ & $10.87 \pm 3.13$ & $906 \pm 272$ & 50.67 & 1.96 & 2.70 & 27.41 \\
\hline 24CA_13 & $32.01 \pm 6.08$ & $35.55 \pm 5.33$ & $32.60 \pm 4.24$ & $9.13 \pm 1.99$ & $1008 \pm 302$ & 45.64 & 1.86 & 2.12 & 12.26 \\
\hline 40CA_13 & $32.44 \pm 5.84$ & $40.71 \pm 6.11$ & $30.30 \pm 3.94$ & $22.94 \pm 5.01$ & $2367 \pm 710$ & 132.03 & 1.87 & 2.69 & 30.48 \\
\hline $11 \mathrm{CA}-13$ & $58.40 \pm 9.93$ & $63.32 \pm 7.60$ & $59.9 \pm 6.59$ & $6.59 \pm 1.18$ & $1109 \pm 333$ & 64.99 & 2.06 & 2.23 & 7.62 \\
\hline $12 \mathrm{CA}-13$ & $23.37 \pm 4.91$ & $26.66 \pm 5.60$ & $23.45 \pm 4.92$ & $12.19 \pm 3.98$ & $962 \pm 289$ & 44.96 & 1.83 & 2.38 & 23.11 \\
\hline 21CA_13 & $34.41 \pm 6.19$ & $38.47 \pm 5.39$ & $33.74 \pm 4.72$ & $11.42 \pm 2.49$ & $1283 \pm 385$ & 60.78 & 1.83 & 2.38 & 23.11 \\
\hline 31CA_13 & $19.52 \pm 5.08$ & $21.61 \pm 3.89$ & $18.92 \pm 5.49$ & $11.06 \pm 4.15$ & $792 \pm 238$ & 33.97 & 1.88 & 2.23 & \\
\hline CA_10_16 & $8.94 \pm 3.40$ & $11.45 \pm 2.98$ & $8.20 \pm 3.53$ & $25.15 \pm 13.90$ & $872 \pm 262$ & 41.36 & 1.90 & 2.54 & 25.20 \\
\hline $\mathrm{CA} 12 \_16$ & $23.13 \pm 4.86$ & $35.25 \pm 5.29$ & $25.13 \pm 5.28$ & $31.55 \pm 8.96$ & $3146 \pm 944$ & 139.57 & 1.66 & 2.35 & 29.36 \\
\hline 33ट्टA_13 & $44.08 \pm 7.93$ & $48.40 \pm 6.78$ & $43.21 \pm 5.19$ & $9.82 \pm 1.99$ & $1288 \pm 386$ & 66.11 & 1.84 & 2.12 & 13.21 \\
\hline \multicolumn{10}{|c|}{ Vent Facies Kimberlites } \\
\hline CA_16_16 & $11.93 \pm 3.10$ & $13.14 \pm 3.42$ & $12.21 \pm 3.54$ & $8.14 \pm 3.49$ & $135 \pm 41$ & 15.93 & 1.97 & 2.02 & 2.48 \\
\hline CA_17-16 & $10.84 \pm 3.04$ & $12.42 \pm 3.48$ & $11.35 \pm 3.52$ & $10.67 \pm 4.90$ & $102 \pm 31$ & 17.43 & 1.74 & 1.83 & 4.92 \\
\hline 2009_477 & $14.11 \pm 3.81$ & $15.89 \pm 4.13$ & $15.27 \pm 3.82$ & $7.55 \pm 3.00$ & $212 \pm 64$ & 18.96 & 2.09 & 2.16 & 3.24 \\
\hline $2013-262$ & $13.64 \pm 3.41$ & $15.03 \pm 4.06$ & $14.14 \pm 4.10$ & $7.58 \pm 3.30$ & $98 \pm 29$ & 18.60 & 2.16 & 2.17 & 0.46 \\
\hline 37CA_13 & $31.17 \pm 4.99$ & $31.46 \pm 4.40$ & $30.64 \pm 4.29$ & $1.76 \pm 0.38$ & $56 \pm 17$ & 9.84 & 2.35 & 2.37 & 0.84 \\
\hline
\end{tabular}

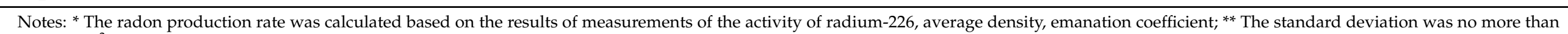
$0.02 \mathrm{~g} \cdot \mathrm{cm}^{-3} ; * * *$ The porosity parameter is calculated based on the results of measurements of the average and true density. 


\section{Appendix B}

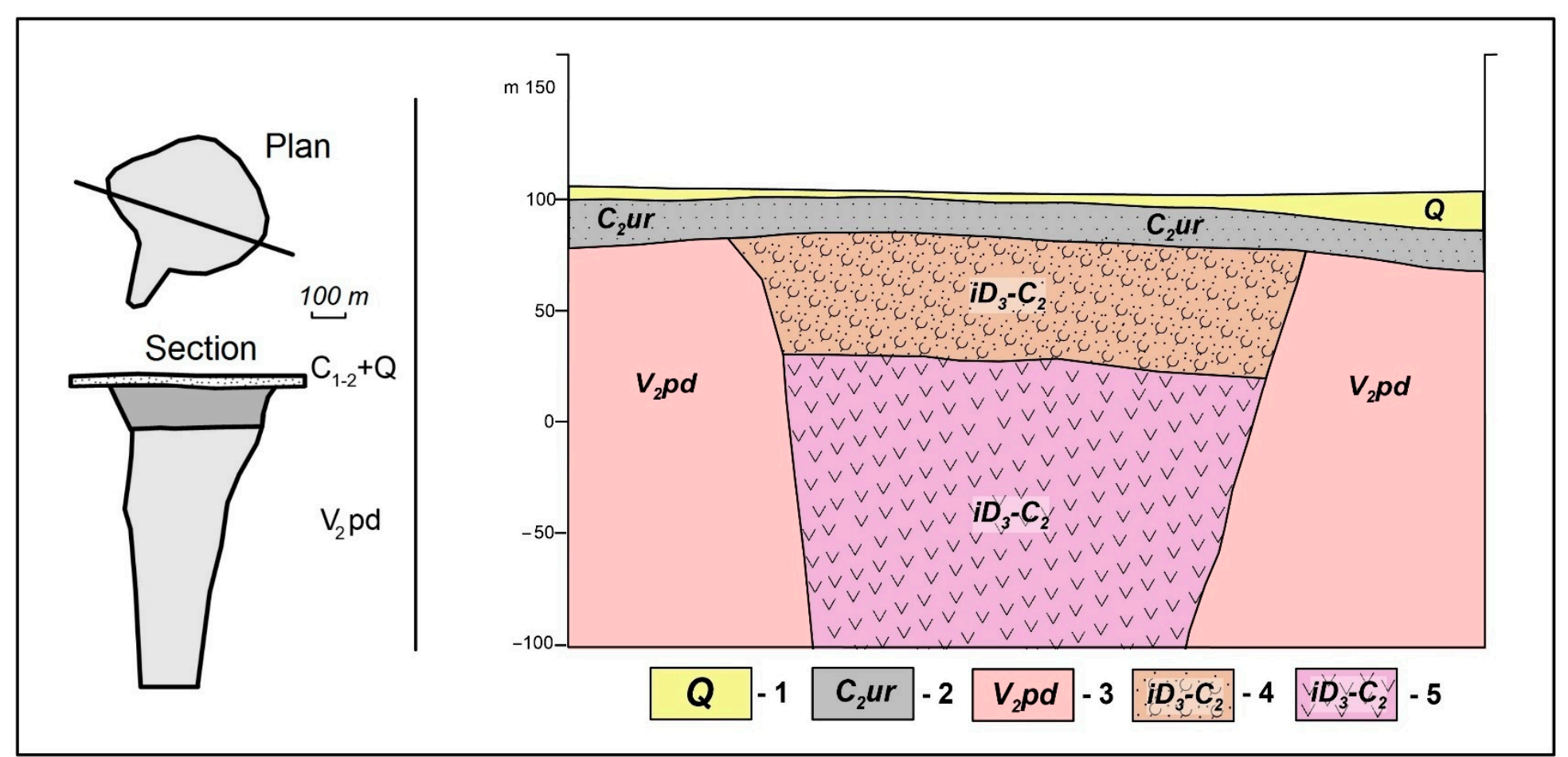

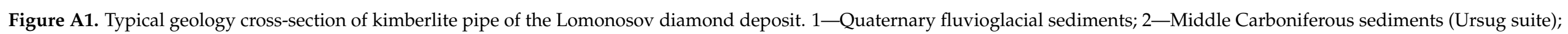
3-Upper Vendian sediments (host rocks of the near-pipe space); 4-Tuffaceous-sedimentary rocks of the crater facies; 5-Kimberlites of the vent facies. 
Appendix C. Typical Types of the Studied Rocks from the Lomonosov Diamond Deposit

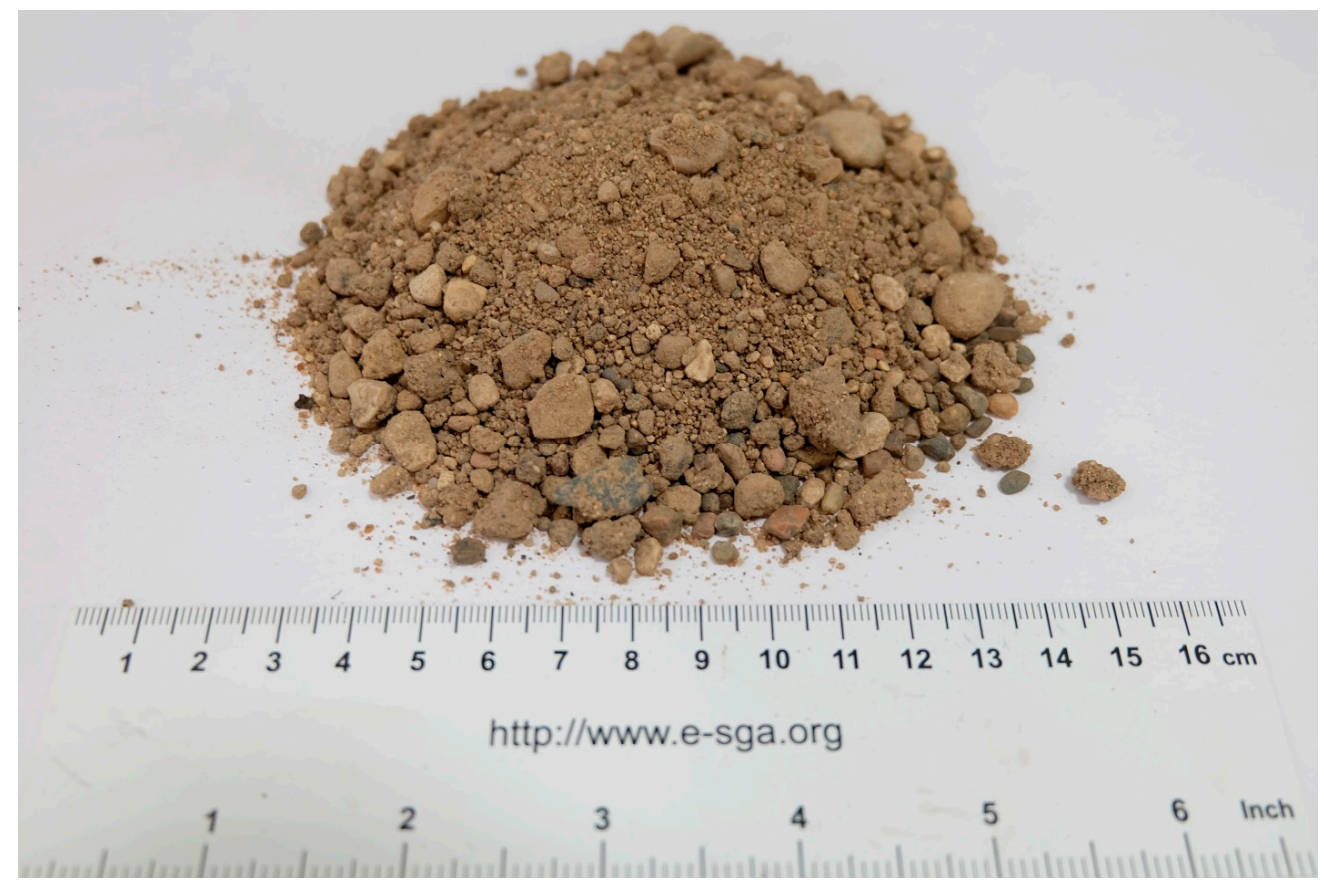

Figure A2. Moraine sand and gravel mix (sample ID 7CA-13), overlying Quaternary fluvioglacial sediments (Q), Lomonosov diamond deposit.

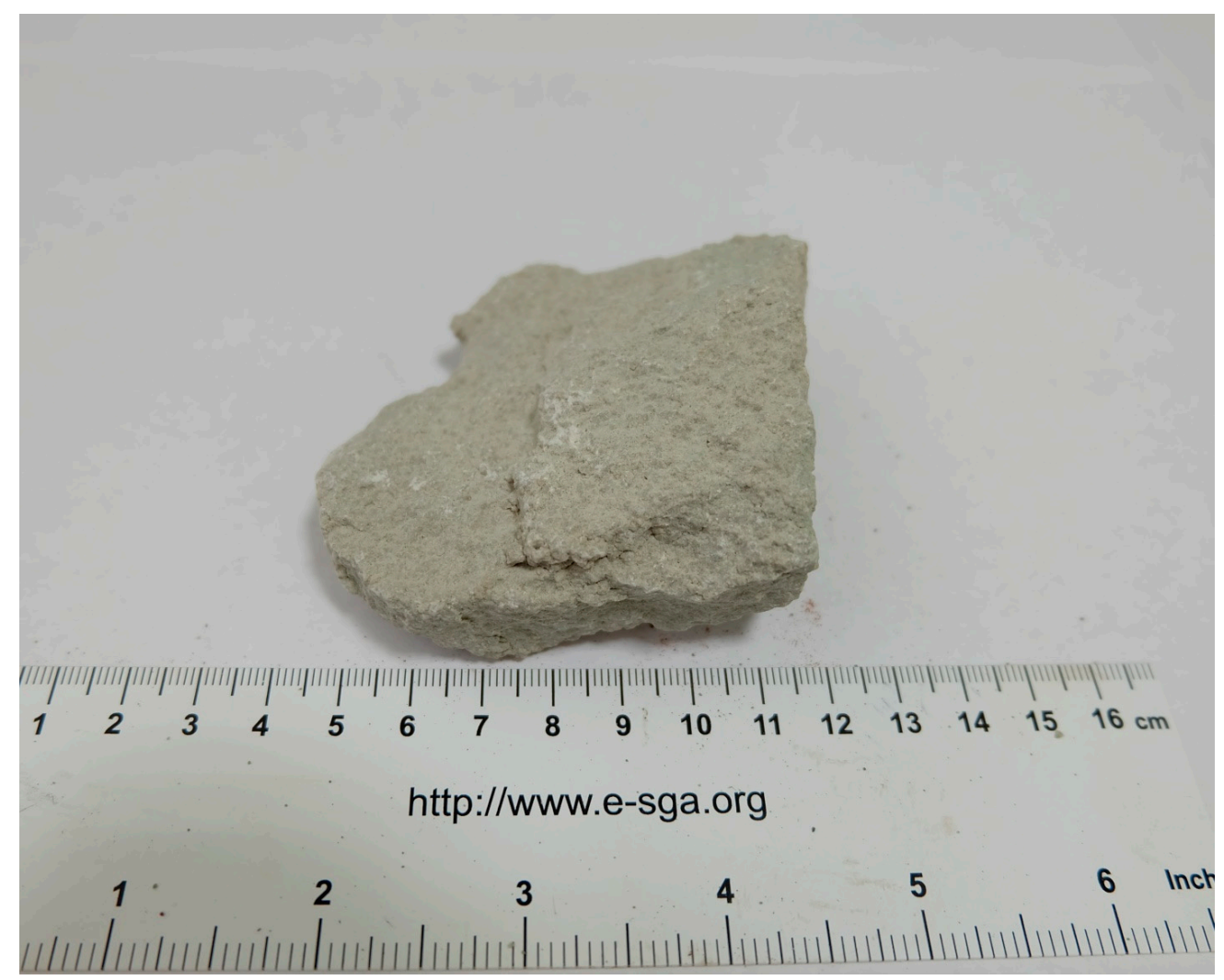

Figure A3. Gray sandstone with calcareous and clay cement (sample ID GGS _2_10_20), overlying Middle Carboniferous rocks, Ursug suite $\left(C_{2} u r\right)$, Lomonosov diamond deposit. 


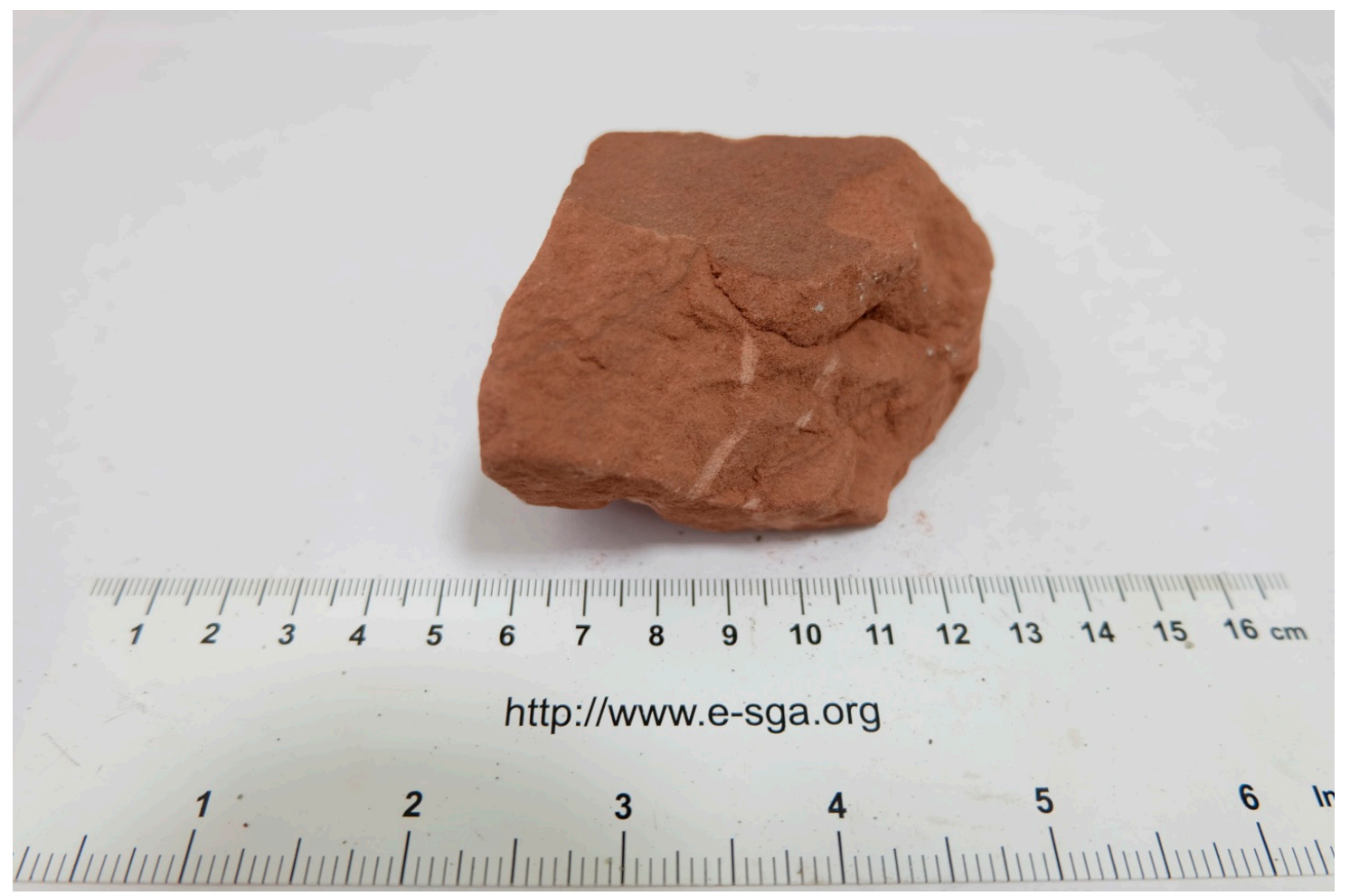

Figure A4. Red sandstone (sample ID 24CA_13), Vendian enclosing rocks of the near-pipe space $\left(V_{2}\right)$, Arkhangelskaya pipe.

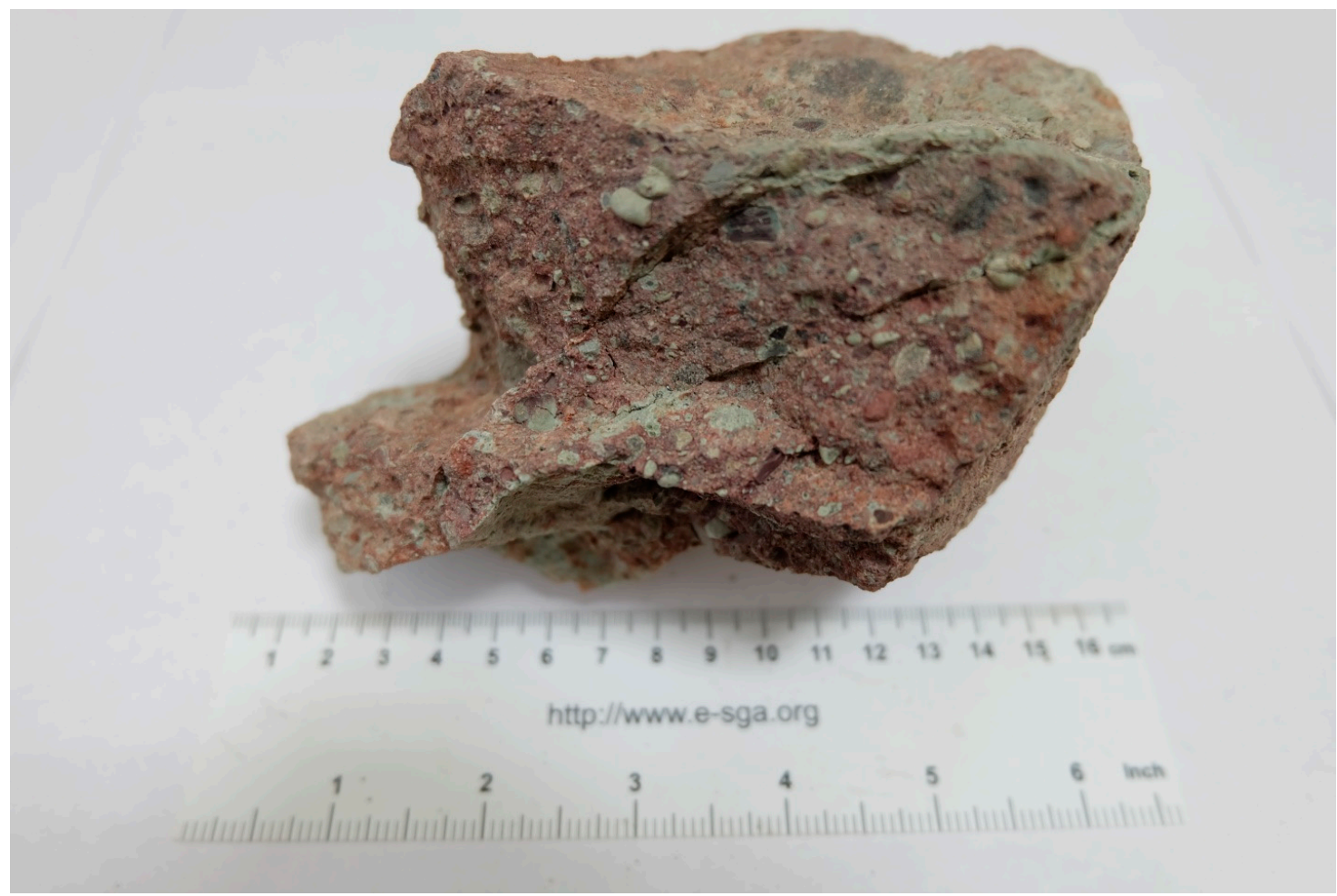

Figure A5. Tuff (sample ID 33CA_13), Tuffaceous sedimentary rocks of the crater, Upper Devonian-Middle Carboniferous $\left(i D_{3}-C_{2}\right)$, Arkhangelskaya pipe, Lomonosov diamond deposit. 


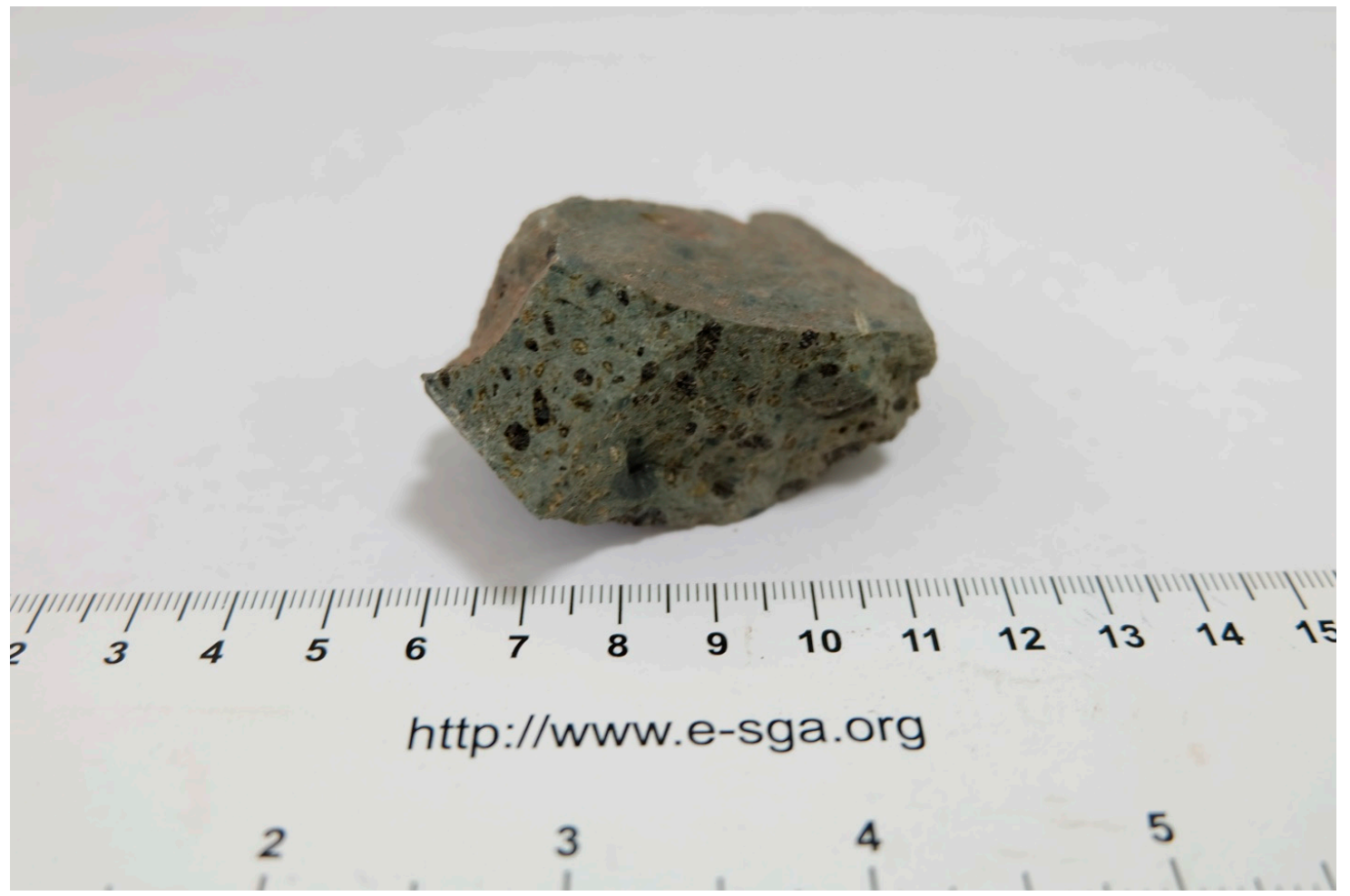

Figure A6. Autolithic breccia (sample ID 37CA_13), Vent Facies Kimberlites (diatreme), Upper Devonian-Middle Carboniferous $\left(i D_{3}-C_{2}\right)$, Arkhangelskaya pipe.

\section{References}

1. Sabbarese, C.; Ambrosino, F.; D'Onofrio, A.; Pugliese, M.; La Verde, G.; D'Avino, V.; Roca, V. The first radon potential map of the Campania region (southern Italy). Appl. Geochem. 2021, 126. [CrossRef]

2. Giustini, F.; Ciotoli, G.; Rinaldini, A.; Ruggiero, L.; Voltaggio, M. Mapping the geogenic radon potential and radon risk by using Empirical Bayesian Kriging regression: A case study from a volcanic area of central Italy. Sci. Total Environ. 2019, 661. [CrossRef]

3. Miklyaev, P.; Petrova, T. Studies of emanation of clay rocks by radon. Geoecology. Eng. Geol. Hydrogeol. Geocryol. $2010,1,13-22$.

4. Baskaran, M. Radon: A Tracer for Geological, Geophysical and Geochemical Studies; Springer: Berlin/Heidelberg, Germany, 2016; p. 260. [CrossRef]

5. Daraktchieva, Z.; Wasikiewicz, J.M.; Howarth, C.B.; Miller, C.A. Study of baseline radon levels in the context of a shale gas development. Sci. Total Environ. 2021, 753. [CrossRef] [PubMed]

6. Loisy, C.; Cerepi, A. ${ }^{222} \mathrm{Rn}$ as a tracer of water-air dynamics in the unsaturated zone of a geological carbonate formation: Example of an underground quarry (Oligocene Aquitain limestone, France). Chem. Geol. 2012, 296-297. [CrossRef]

7. Kuo, T.; Tsunomori, F. Estimation of fracture porosity using radon as a tracer. J. Pet. Sci. Eng. 2014, 122. [CrossRef]

8. Selvam, S.; Muthukumar, P.; Sajeev, S.; Venkatramanan, S.; Chung, S.Y.; Brindha, K.; Babu, D.S.S.; Murugan, R. Quantification of submarine groundwater discharge (SGD) using radon, radium tracers and nutrient inputs in Punnakayal, south coast of India. Geosci. Front. 2021, 12. [CrossRef]

9. Sahoo, S.K.; Katlamudi, M.; Barman, C.; Lakshmi, G.U. Identification of earthquake precursors in soil 222Rn data of Kutch, Gujarat, India using empirical mode decomposition based Hilbert Huang Transform. J. Environ. Radioact. 2020, 222. [CrossRef]

10. Kawabata, K.; Sato, T.; Takahashi, H.A.; Tsunomori, F.; Hosono, T.; Takahashi, M.; Kitamura, Y. Changes in groundwater radon concentrations caused by the 2016 Kumamoto earthquake. J. Hydrol. 2020, 584. [CrossRef]

11. Moreno, V.; Bach, J.; Zarroca, M.; Font, L.; Roqué, C.; Linares, R. Characterization of radon levels in soil and groundwater in the North Maladeta Fault area (Central Pyrenees) and their effects on indoor radon concentration in a thermal spa. J. Environ. Radioact. 2018, 189. [CrossRef]

12. Tsapalov, A.; Kovler, K.; Miklyaev, P. Open charcoal chamber method for mass measurements of radon exhalation rate from soil surface. J. Environ. Radioact. 2016, 160. [CrossRef]

13. Yang, Y.; Li, Y.; Guan, Z.; Chen, Z.; Zhang, L.; Lv, C.J.; Sun, F. Correlations between the radon concentrations in soil gas and the activity of the Anninghe and the Zemuhe faults in Sichuan, southwestern of China. Appl. Geochem. 2018, 89. [CrossRef]

14. Domingos, F.; Pereira, A. Implications of alteration processes on radon emanation, radon production rate and W-Sn exploration in the Panasqueira ore district. Sci. Total Environ. 2018, 622-623, 825-840. [CrossRef] [PubMed] 
15. Pinto, P.V.; Sudeep Kumara, K.; Karunakara, N. Mass exhalation rates, emanation coefficients and enrichment pattern of radon, thoron in various grain size fractions of monazite rich beach placers. Radiat. Meas. 2020, 130. [CrossRef]

16. McDowall, G.; Koketso, H. Radon emanometry over some kimberlites and lamproites in Southern and Western Botswana. In Proceedings of the 53rd EAEG Meeting; European Association of Geoscientists E Engineers; European Association of Geoscientists \& Engineers: Houten, The Netherlands, 1991. [CrossRef]

17. Bobrov, A. Reflections of some features of the fault zones of the Olkhon and southern Angara regions in radon emanations. Tectonophys. Top. Issues Earth Sci. 2009, 2, 5-9.

18. Magomedova, A.; Udoratin, V. Volumetric activity of radon in pipes of explosion and magnetic anomalies of the Middle Timan. Bull. IG Komi Sci. Cent. Ural Branch RAS 1991, 10, 28-34.

19. Kiselev, G.P.; Yakovlev, E.Y.; Druzhinin, S.V.; Zykov, S.B.; Bykov, V.M.; Ocheretenko, A.A. Uranium even isotopes in kimberlites, enclosing and overburden rocks of the Zolotitskoye ore field (Arkhangelsk diamondiferous province). Russ. J. Earth Sci. 2018, 18. [CrossRef]

20. Kiselev, G.P.; Danilov, K.B.; Yakovlev, E.U.; Druzhinin, S.V. Radiometric and seismic study of Chidvinskaya kimberlite pipe (Arkhangelsk diamondiferous province, North of the East European Craton, Russia). Geofísica Int. 2017, 2, 147-155.

21. Zaripov, N.R. Clarification of the Red-Colored Rocks of the Zimneberezhny Diamondiferous Region of the Arkhangelsk Province and the Nakynsky Diamondiferous Field of the Yakut Province, Its Connection with the Kimberlite Control Structures. Ph.D. Thesis, Sergo Ordzhonikidze Russian State University for Geological Prospecting, Moscow, Russia, 2017.

22. Yakovlev, E.Y. Features of radioactive element distribution within the Arkhangelsk diamondiferous province: Possible directions for development of isotope-radiogeochemical methods for kimberlite prospecting in complex landscape-geology and climate conditions of the subarctic zone. Geochem. Explor. Environ. Anal. 2020, 20, 269-279. [CrossRef]

23. Syam, N.S.; Lim, S.; Lee, H.Y.; Lee, S.H. Determination of radon leakage from sample container for gamma spectrometry measurement of 226Ra. J. Environ. Radioact. 2020, 220-221. [CrossRef]

24. IAEA. IAEA Annual Report for 2013; International Atomic Energy Agency: Vienna, Austria, 2013.

25. Mauring, A.; Gäfvert, T. Radon tightness of different sample sealing methods for gamma spectrometric measurements of 226Ra. Appl. Radiat. Isot. 2013, 81. [CrossRef]

26. Tsapalov, A.; Miklyaev, P.; Petrova, T. The principle of detecting areas with active geodynamics based on the analysis of the $210 \mathrm{~Pb} / 226 \mathrm{Ra}$ activity ratio in soil samples. ANRI 2013, 1, 9-11.

27. Afonin, A.; Korchunov, A. Optimizing block parameters measurements for monitoring radon, thoron and their daughter products in various environments. ANRI 2013, 1, 9-11.

28. International Atomic Energy Agency. Measurement and Calculation of Radon Releases from NORM Residues, Technical Reports Series; International Atomic Energy Agency: Vienna, Austria, 2013; Volume 474.

29. Pereira, A.; Lamas, R.; Miranda, M.; Domingos, F.; Neves, L.; Ferreira, N.; Costa, L. Estimation of the radon production rate in granite rocks and evaluation of the implications for geogenic radon potential maps: A case study in Central Portugal. J. Environ. Radioact. 2017, 166. [CrossRef]

30. Phong Thu, H.N.; Van Thang, N.; Hao, L.C. The effects of some soil characteristics on radon emanation and diffusion. J. Environ. Radioact. 2020, 216. [CrossRef]

31. Soniya, S.R.; Abraham, S.; Khandaker, M.U.; Jojo, P.J. Investigation of diffusive transport of radon through bricks. Radiat. Phys. Chem. 2021, 178. [CrossRef]

32. Zinchuk, N.; Zinchuk, M. Petrophysical properties of kimberlites and host rocks in prospective territories of the East European platform. Collect. Sci. Work. UkrDGRI 2014, 1, 97-108.

33. Burmistrov, A.; Garanin, K.; Starostin, V.; Yuzhakov, L. Comparative analysis of the petrophysical parameters of the porphyry kimberlites of the V. Grib pipes (Arkhangelsk region) and Aikhal (Yakutia). Geol. Diam. Present Futur. 2005, 8, 762-772.

34. Burmistrov, A.; Boguslavskiy, M. Petrophysical properties of kimberlites of the Komsomolskaya pipe and their relationship with the peculiarities of its material composition, formation conditions and diamond content. Moscow Univ. Bull. Geol. 2009, 4, 215-224.

35. Arbuzov, S.I.; Rihvanov, L.P. Geochemistry of Radioactive Elements; Tomsk Polytechnic University Publishing House: Tomsk, Russia, $2009 ;$ p. 300.

36. Ignatov, P.A.; Novikov, K.V.; Bushkov, K.Y. Reconstruction of faults kinematics in closed areas according to the analysis of micro-faults in the core. Geol. Explor. 2011, 3, 55-60.

37. Gunin, A.P.; Ignatov, P.A.; Zaripov, N.R.; Novikov, K.V. Signs of exocontacts of kimberlites in the south of the Zolotitsky diamondiferous field of the Arkhangelsk province. New Ideas Earth Sci. 2013, 1, 310-311.

38. Ignatov, P.A.; Gunin, A.P.; Zaripov, N.R. Connection of Manifestations of Alkaline-Ultrabasic Magmatism with the Structures of the Central Type of the East of the Zimneberezhny Area of the Arkhangelsk Region; Sergo Ordzhonikidze Russian State University for Geological Prospecting: Moscow, Russia, 2013; p. 370.

39. Ignatov, P.A. Paleohydrogeological Conditions of Formation of Ore Deposits; Sergo Ordzhonikidze Russian State University for Geological Prospecting: Moscow, Russia, 2014; p. 265.

40. Zaripov, N.R. Clarification (Gleaning) of Red-Colored Vendian-Cambrian Rocks and Its Relationship with Alkaline-Ultrabasic Magmatism of the Arkhangelsk Region; Sergo Ordzhonikidze Russian State University for Geological Prospecting: Moscow, Russia, $2014 ;$ p. 170. 
41. Ignatov, P.A.; Zaripov, N.R.; Kim, V.; Gunin, A.P. Types of clarified red-colored kimberlitic host Vendian-Cambrian rocks of the Zimneberezhny district of the Arkhangelsk region. Geol. Explor. 2015, 2, 15-21.

42. Ignatov, P.A.; Bolonin, A.V.; Vasilyev, I.D.; Shmonov, A.M.; Fomin, A.A.; Kim, V. Folded and discontinuous deformations in the host and overlapping strata in the Arkhangelsk kimberlite pipe. Ores Met. 2012, 1, 42-48.

43. Ignatov, P.A.; Bolonin, A.V.; Kalmykov, B.A. Paleotectonic structures of the Zimneberezhny diamondiferous area of the Arkhangelsk Region. Bull. MOIP 2008, 3, 13-20.

44. Ignatov, P.A.; Bolonin, A.V.; Vasilyev, I.D.; Fomin, A.A.; Kim, V. Contacts of the Arkhangelsk kimberlite pipe and deformations of enclosing and overlapping rocks. Geol. Explor. 2009, 5, 28-34.

45. Novikov, K.V.; Ignatov, P.A. Organization of Databases for Twodimensional Analysis of Fluid Fracturing, Tectonic and Mineralization Features of Kimberlite-Containing Structures; Sergo Ordzhonikidze Russian State University for Geological Prospecting: Moscow, Russia, 2009.

46. Vasilyev, I.D. Geological Structures in the Near-Pipe Zone of the Arkhangelskaya Pipe and Their Use to Find Diamond Deposits in the Zimneberezhny Area. Ph.D. Thesis, Sergo Ordzhonikidze Russian State University for Geological Prospecting, Moscow, Russia, 2010.

47. Vasiliev, I.D.; Ignatov, P.A.; Bolonin, A.V.; Shmonov, A.M. Comparison of Sections and Petrochemical Data on the Kimberlitic Strata of the Lomonosov Diamond Deposit; Sergo Ordzhonikidze Russian State University for Geological Prospecting: Moscow, Russia, 2010; p. 195.

48. Khazanovich-Wulff, K.K. Diatreme Plumes of Astroblem or "Bolide Model" of the Formation of Kimberlite Pipes; Publishing House (Printing House) Moscow State University: Moscow, Russia, 2007; p. 290.

49. Nikitin, B.M. Deformation of host rocks during formation of kimberlite pipes. Petrology 1980, 11, 41-49.

50. Milashev, V.A. Pipes; Nedra: Leningrad, Russia, 1984; p. 268.

51. Malykh, A.V. The Main Features of the Structure of Near-Pipe Space of Tuff Iron Ore and Kimberlite Pipes of the Siberian Platform; Ural State University Publishing House: Ural, Russia, 1989; p. 315.

52. Kiselev, G.P.; Yakovlev, E.Y.; Druzhinin, S.V. Experimental-Methodical and Research Work on the Predictive-Search Assessment of Lomonosov Deposit Areas That Are Promising for the Search for Kimberlite Pipes Using Radiometric Methods; Bulatov Publishing House, Northern Arctic Federal University: Arkhangelsk, Russia, 2016; p. 138.

53. Eakin, M.; Brownlee, S.J.; Baskaran, M.; Barbero, L. Mechanisms of radon loss from zircon: Microstructural controls on emanation and diffusion. Geochim. Cosmochim. Acta 2016, 184, 212-226. [CrossRef] 